\title{
Understanding the contribution of wild edible plants to rural social- ecological resilience in semi-arid Kenya
}

\author{
Stephanie A. Shumsky $^{1}$, Gordon M. Hickey ${ }^{1}$, Bernard Pelletier $^{1}$ and Timothy Johns ${ }^{2,3}$
}

\begin{abstract}
Wild edible plants (WEPs) are known to make important contributions to food baskets and livelihoods in the smallholder and subsistence farming communities of sub-Saharan Africa. As a result, protecting and promoting the sustainable use of WEPs in concert with more mainstream agricultural innovation efforts has the potential to build household resilience to food insecurity. There is, however, a need to better understand how WEPs contribute to rural livelihoods on a daily basis and act as emergency safety nets during periods of hunger. Focusing on two villages in rural eastern Kenya, we sought to determine which household conditions are correlated with household reliance on WEPs as a coping strategy during times of food insecurity, while also investigating the role of access restrictions on adaptive capacity and the ability to obtain these important food resources. Results reveal that reliance on WEPs is greater in households that report food insecurity, lack off-farm income, and have lower asset levels. Access to WEPs is also a major factor in consumption frequency, with smaller farm sizes and increased distance to harvest areas significantly correlated with lower levels of WEP use. By combining vulnerability and adaptive capacity measures for each household, we created a more complete accounting of the factors that influence WEP consumption frequency, with implications for policy. This study represents an important first step in taking a more holistic view of the subsistence value of WEPs and the myriad factors that influence households' reliance on, and ability to obtain, uncultivated natural resources.
\end{abstract}

Key Words: East Africa; food policy; food security; social-ecological system; subsistence agriculture; sustainable livelihoods; Tharaka

\section{INTRODUCTION}

Food insecurity and malnutrition affect much of the world's population (Godfray et al. 2010). Approximately two billion people, representing every country on earth, are estimated to suffer from micronutrient deficiencies that make them more susceptible to disease, and that can be a significant obstacle to economic growth (FAO 2012). These food security issues are especially severe in the largely import-dependent countries of subSaharan Africa (FAO 2011b), where price shocks in 2006-2008 affected an estimated 12 million people (Moseley 2012), and projected crop yield declines due to climate change are expected to be particularly severe because of existing environmental degradation (CIDA 2004) and reliance on manual farming and low levels of technology (Brown and Funk 2008, Müller et al. 2011).

Many of the interventions and policies designed to mitigate the potential negative impacts of climate change on food production are beginning to emphasize resilience, i.e., a combination of flexibility in the face of disturbance and capacity to adapt to change (Ifejika Speranza 2010). Recent climate change assessments have identified low levels of adaptive capacity as one of the main drivers of vulnerability in Africa, largely due to the prevalence of extreme poverty, extreme weather (primarily drought), low levels of yield-enhancing technology, and general lack of infrastructure (Easterling et al. 2007, Müller et al. 2011). Although a number of studies have sought to address the importance of adaptive capacity in farming systems (Adger and Vincent 2005, Below et al. 2012), particularly as seen through national socioeconomic and government indicators (Brooks et al. 2005) and in response to natural disasters (Yohe and Tol 2002), to our knowledge, few have considered the role of existing strategies within local social-ecological systems.

\section{Wild edible plants as a strategy to increase social-ecological resilience}

Rural communities that lack resilience and are highly sensitive to environmental perturbations tend to rely on a range of strategies to minimize system vulnerability (Davies 1993). These "portfolios of options" can include straightforward measures such as reducing food intake or selling livestock for income to cope with periods of food insecurity, or more complex, long-term actions such as migration (Davies 1993). Wild edible plants (WEPs), defined by the Food and Agriculture Organization (FAO) as "plants that grow spontaneously in self-maintaining populations in natural or semi-natural ecosystems and can exist independently of direct human action" (Heywood 1999:2), have been identified as a particularly important way that households in rural Africa can reduce their sensitivity to environmental change while also adapting to less favourable conditions. For the purposes of this study, all plants that are gathered (i.e., not cultivated) are considered wild, including species harvested in agricultural areas, uncultivated areas, or forestland (following Termote et al. 2011).

The key characteristics of WEPs are as follows:

1. They are locally available and their use is based on traditional ecological knowledge (Pardo-De-Santayana et al. 2005, Jman Redzic 2006, Arenas and Scarpa 2007).

2. They are a low-input, low-cost option for increasing nutrition and reducing the need to spend limited cash resources (Shackleton and Shackleton 2004, Jama et al. 2008).

3. They provide greater benefits to vulnerable populations (poorer households, women, and children; Grivetti and Ogle 2000, Fentahun and Hager 2009), who are often

${ }^{1}$ Department of Natural Resource Sciences, McGill University, ${ }^{2}$ Centre for Indigenous Peoples' Nutrition and Environment, McGill University,

${ }^{3}$ School of Dietetics and Human Nutrition, McGill University 
disproportionately affected by climate events (Eriksen and O'brien 2007).

4. They contribute to livelihoods and are available during times of drought or conflict-driven famine (Gordon and Enfors 2008, Muller and Almedom 2008, Strauch et al. 2008).

5. They tolerate water stress better than their domesticated relatives (Humphry et al. 1993, Addis et al. 2005), possessing an "innate resilience to rapid climate change, which is often lacking in exotic species" (Fentahun and Hager 2009:208).

Considering the importance of WEPs to household food security, it is essential that the social-ecological systems that make gathering these natural resources possible be appropriately protected, managed, and valued to avoid overexploitation and degradation (Feyssa et al. 2011). Better understanding of ethnobotanical knowledge and WEP users is necessary to inform agricultural development, natural resource management, and food security policies that could facilitate more sustainable access to these resources and even increase their positive impact on community resilience (Termote et al. 2010, Mavengahama et al. 2013). Studies have shown that inappropriate regulation of WEPs can take several forms, from unmitigated open access, which can result in unsustainable harvest levels and degradation (Stewart 2003), to poorly targeted restrictions that exclude populations relying on WEPs as a major nutrition source (Falconer 1990) or push them to purchase alternative foods at the market using scarce cash resources (Sandemose 2009). To date, the relative exclusion of WEPs from agriculture-related scientific research, development, and policy has likely had a detrimental effect on rural household nutrition because WEP production, consumption, and diversity have declined (Dansi et al. 2008). This is a time-sensitive issue, requiring the identification and protection of local indigenous knowledge systems that inform the collection and use of WEPs (Tabuti et al. 2004).

\section{Research objective}

Despite recognition that WEPs are an important dietary component for at least one billion people worldwide (Burlingame 2000), significant questions remain regarding which demographic groups rely on these resources and where they are obtained in times of low food availability and financial stress. Ethnobotanical studies have investigated the various household factors that affect local ecological knowledge (LEK) and use of wild foods, such as income level, proximity to local markets, and the age, sex, and education level of the head of household (Somnasang and Moreno-Black 2000, Byg and Balslev 2001, Reyes-García et al. 2005). The issue has also been approached from a resource management perspective, where conservation restrictions, land tenure, community organizations, and environmental conditions have been correlated with changes in WEP consumption (Ladio and Lozada 2003, Paumgarten 2005, Devineau et al. 2008). Farm size is a particularly interesting variable because more private land provides greater unabated access to WEPs for the owners who can harvest these resources while farming (Price 1997), but may not be inclined to do so because households with greater wealth and assets often avoid WEPs due to the social stigma of eating the "food of the poorest" (Kepe 2008:543). These previous studies provide the starting point for our research into the factors affecting access to WEPs and their contribution to household food security in semi-arid Kenya.
We have previously investigated the policy consequences of conflating subsistence collection of WEPs for use in the home with large scale commercial harvests intended to generate additional income (Shumsky et al. 2014), an especially acute issue in the areas we studied, as we did not encounter a single case in which the motivation for a WEP harvest event was solely market oriented, and we recorded only three species in local markets as being collected for both consumption and sale. For this reason as well as evidence presented elsewhere suggesting the harm caused by focusing research, policy, and development interventions on nontimber forest product (NTFP) harvest for local and international markets (Arnold and Pérez 2001, Brown and Lapuyade 2001, Kusters et al 2006, Sick 2008, Peach Brown and Lassoie 2010, among others), we treat WEPs in the area we studied as an important source of supplementary nutrition collected by individuals for use in their own homes. The main exception to this was the occasional harvest and sale of muthithi(Tamarind indicus) fruits to a local businessman in Chiakariga for approximately 10 $20 \mathrm{Ksh} / \mathrm{kg}(\$ 0.12-0.25 \mathrm{CAD} / \mathrm{kg})$, which had been collected from trees located mostly in the home compound or private family farms. Market research studies in Kenya (Bester 1999) and our interviews with value-chain actors from the private sector, forest service, and agriculture extension agents indicate that in the study area, income generation from NTFPs is difficult to achieve because of high transportation costs, decreasing availability of produce, and unstable export commodity markets (see Shumsky et al. 2014 for analysis).

We begin our analysis by presenting an overall description of WEP consumption in two communities, providing information on levels of WEP harvest, types of areas from which they are harvested, motivations behind their use, and how their consumption varies geographically and seasonally. We then examine the role of WEPs in more depth using an integrated resilience framework, grouping variables potentially affecting WEP consumption under two headings:

1. System sensitivity/vulnerability: the likelihood of suffering consequences from environmental or social changes (Kelly and Adger 2000, Eriksen et al. 2005). These variables included household food insecurity and assets, number of children, and off-farm employment, as well as age, education, residency, and marital status of the household head.

2. Adaptive/coping capacity: the ability to overcome system instability by working within existing infrastructure and alternative livelihood strategies. This term also refers to framework evolution over time, although not directly observed in this case study (Eriksen et al. 2005, Nelson et al. 2010). Three main areas were considered in this case: (1) local ecological knowledge (LEK; Somnasang and MorenoBlack 2000); (2) access, using proximity to harvest areas and farm size as proxies (Pardo-De-Santayana et al. 2005, Arenas and Scarpa 2007); and (3) regulation, in terms of harvest restrictions on public land and permission requirements for private holdings (Widayati et al. 2010).

These factors were used as independent variables to analyze household-level WEP consumption, as well as changes in individual species collection rates from each specific harvest area. WEP species richness was also considered by recording each of 
the plants individually, with their respective collection site, consumption frequency, and reasons for harvest. Ultimately, we undertook to delineate the demographic groups and harvest locations that could be targeted by policy makers, development practitioners, and extension programs to sustain WEP harvest as part of a resilient food system. Our results can be used to limit actions and policies that reduce WEP availability, which Bharucha and Pretty (2010) suggest will increase the contribution that these resources make to household food security and mitigating gaps between food supply and demand.

\section{METHODS}

\section{Study area}

This project was conducted as part of a multidisciplinary research partnership between the Kenya Agricultural Research Institute (KARI) and McGill University ${ }^{[1]}$. The main objective of this larger project was to enhance food and nutritional security of rural households in semi-arid Kenya by understanding and encouraging the adoption of techniques that enhance the socialecological resilience of smallholder farming systems.

To better understand the factors affecting use and access to WEPs in semi-arid Kenya, we used a case study research design (Yin 2009) focusing on two farming communities in southern Tharaka Constituency (Fig. 1), Nyukani ( $0^{\circ} 17^{\prime}$ S, $\left.37^{\circ} 56^{\prime} \mathrm{E}\right)$ and Gantundu $\left(0^{\circ} 15^{\prime} \mathrm{S}, 37^{\circ} 52^{\prime} \mathrm{E}\right)$, where food insecurity is prevalent due to regular droughts and crop failure (KFSSG 2011). Both villages are located in the semi-arid region, dominated by a mixed livelihood system of livestock; some formal sector income; and marginal/subsistence farming of maize, millet, sorghum, cowpeas, pigeon peas, cassava, and green grams (mung beans), as well as cash crops such as tea, coffee, horticultural species, and cotton. The annual rainfall fluctuates between 200 and $800 \mathrm{~mm}$ and falls mostly during the "short" rains (October-December) and the "long" rains in April. Elevation varies considerably, from 690 to $>1400 \mathrm{~m}$ above sea level at the top of Kijege Hill (Wisner 1977). These communities were selected based on criteria that included: (1) the prevalence and intra-community variation of WEP consumption, (2) the diversity of livelihood strategies, and (3) their proximity to harvest sites covering a spectrum of access conditions (P. Maundu, Kenya National Museum and Bioversity International, personal communication).

The two case study sites were chosen to encompass a variety of public, private, and community-managed lands to appropriately represent diverse local opinions. The village of Gantundu comprises 108 households and is situated in the Nkarini sublocation. The village of Nyukani comprises 54 households and is in the Chiakariga sublocation. Nyukani is $<1 \mathrm{~km}$ from the bustling town of Chiakariga, which has weekly market days. Chiakariga is also the main commerce site for the village of Gantundu, located approximately $15 \mathrm{~km}$ to the west. Nyukani sits at the foot of a 3303-ha protected forest, Kijege Hilltop Reserve, which has been managed by the Kenyan Forestry Service for conservation objectives, watershed protection, and soil preservation since 1959 (IUCN and UNEP 2010). Settlement on this hilltop has been restricted since colonial times, leaving the forest essentially intact (Smucker and Change 2002).
Fig. 1. Map of the study locations in Tharaka District, eastern Kenya. Source: Shumsky et al. (2014).

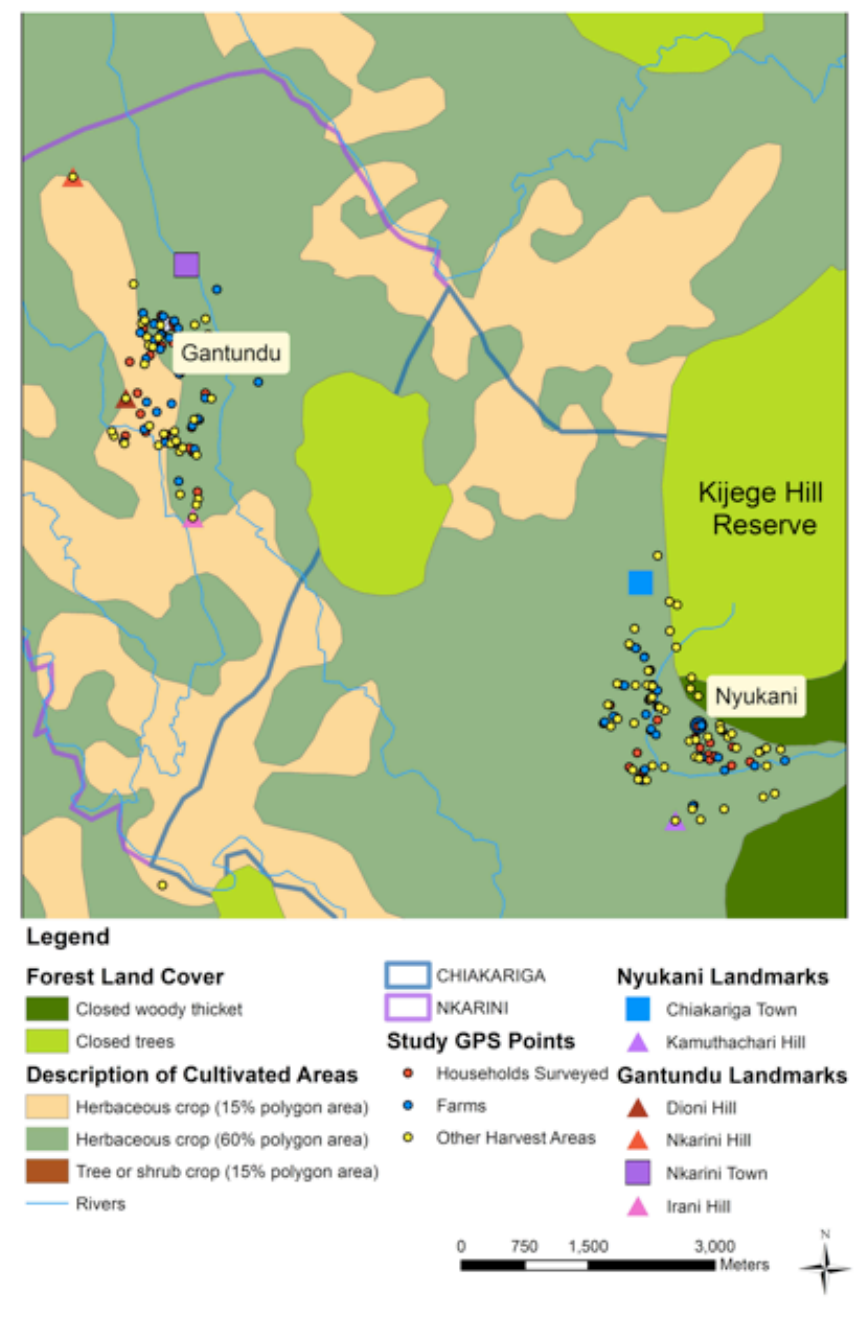

\section{Data collection}

The contemporary nature of this project made case study research appropriate, allowing for the inclusion of diverse evidence from observation, documentation, and interviews (Yin 2009). To address our research questions more fully, we used the mixed methods approach to minimize the limitations and biases inherent to data collection in the field and to develop more accurate results through the triangulation of different data sources (Creswell 2003). Data collection included a quantitative household survey and a variety of participatory activities, interviews, and group discussions. Spatial information was then integrated into all aspects of the study through a combination of GIS analysis and participatory mapping activities, further discussed in the following sections.

\section{Household surveys and interviews}

We conducted household surveys in two communities focused on household demographics, family structure, household food security, land tenure, and access to natural areas. Information on 
the harvest and consumption of WEPs from the home, farm, and other privately owned or public lands over a calendar year was collected, including the reasons for harvesting, preparation techniques, and the identification of distinct collectors and consumers of each plant (see Dansi et al. 2008). Throughout the study, we considered WEP harvest and consumption to be equivalent, i.e., WEPs are usually consumed shortly after harvest. In addition, we identified no harvest events motivated solely by income generation, and the exceptional case of only three species collected with dual income and subsistence benefits in mind, of the total of 60 species recorded during data collection. The overwhelming majority of the dual-purpose harvests $(97 \%)$ were of Tamarind indica, collected most often by households on their own farms, and in some cases, from homesteads and other areas as well. At the conclusion of each survey, a semi-structured interview was conducted with the respondent to clarify any inconsistencies in the survey and to gain a better understanding of local opinions and concerns regarding WEPs, cultural considerations, and the implications of changes in climate, land tenure, and access to common property resources (see Shumsky et al. 2014). All the harvest locations mentioned by participants were visited and georeferenced using a handheld GPS for use in GIS analysis.

In total, 60 households were randomly selected from a list obtained from the village elders in each study site using a random number generator in Excel from a total of 162 households (108 in Gantundu and 54 in Nyukani) and then located with the help of a field assistant. KARI-trained enumerators collected primary data using the assistance of local field assistants. The survey, conducted in the Kitharaka language, was designed according to the guidelines for quantitative data collection in developing countries (United Nations 2008) and evolved through input from project team members, experts in the field, and local participants during pre-testing. The main purpose of the household survey was not to make statistical inference applicable to other semi-arid regions of Kenya but to provide a representative picture of the variety of livelihoods and conditions and corresponding household WEP harvest behaviors encountered in the study area (see Ellis and Bahiigwa 2003, Ellis and Mdoe 2003, Ellis and Freeman 2004).

\section{Qualitative data collection and participatory activities}

In addition to the information gathered from selected households, the community as a whole had several opportunities to attend meetings and engage in activities in which their unique knowledge could be shared, debated, and included as an important component of the study. Focus group sessions and participatory activities were conducted with the assistance of local facilitators (Sutherland et al. 1999, Campbell et al. 2001, Kuhnlein et al. 2004, Günther and Vogl 2010). These meetings took place over the duration of the field season (June 8-September 12, 2012), providing an opportunity for community input on the research design and results dissemination. These activities also served to gather the background information necessary to contextualize the data collected through surveys, interviews, and subsequent focus group sessions. At the start of the season in June 2012, a community meeting was held to discuss the goals and requirements of the project. After the initial presentation, an informal focus group discussion was conducted to determine the WEPs known to the community, their importance to food security and cultural traditions, and the degree to which each species was appreciated. The participants at each study site also attended a seasonal mapping session in which dried maize was used to represent relative abundance of various assets and resources and then graphed using the seasons described by community members (Fig. 2). At each study site, the focus groups were divided into two sub-groups, all of which had slightly different seasonal calendars and different perceptions of annual variation in WEP availability as well as household food security and farm productivity. The WEPs were divided into a few groups by type and harvest location to simplify the exercise because going through each species' seasonal availability individually would have taken many more hours.

Although our main objective was not to conduct an ethnobotanical survey of the area, information about the local names and uses of various species was obtained. Botanical

Fig. 2. Relative abundance of food from farms and household cash resources (from the sale of agricultural produce and other sources) as estimated using seasonal mapping activities in which participants allocated a proportion of dried maize/beans to each season. Groups 1 and $2=$ Gantundu, Groups 3 and $4=$ Nyukani. Five seasons were delineated by each group of participants, with the first hot/dry season corresponding to January.

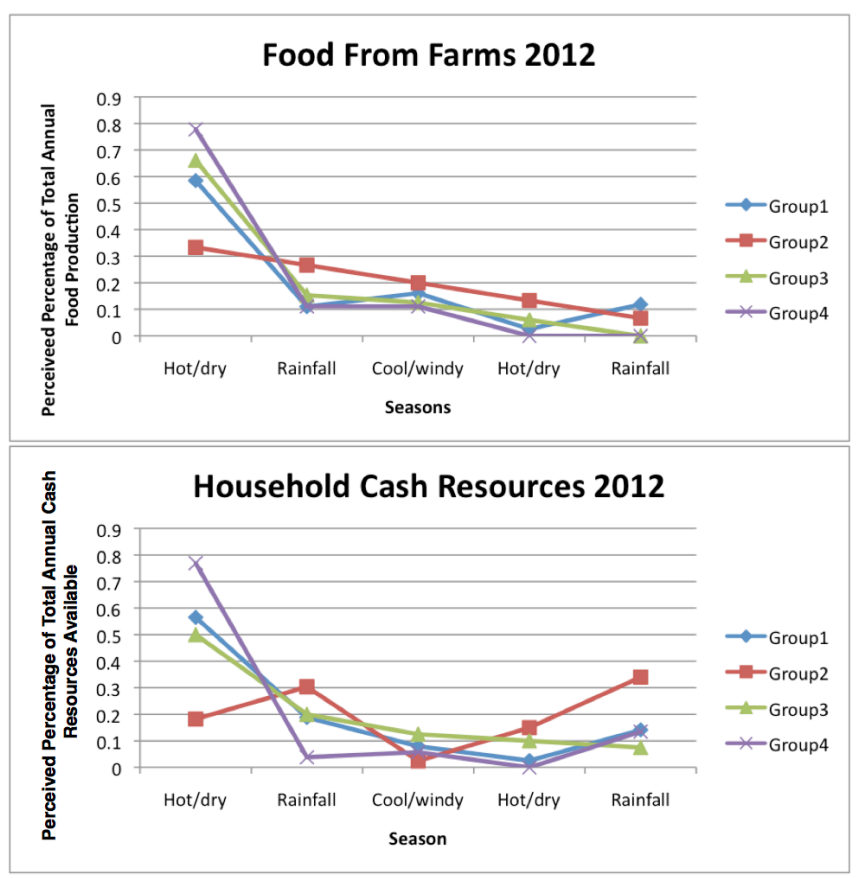

Seasons approximately correspond to the followings months as described by participants, can vary by year and arrival of the annual rains.

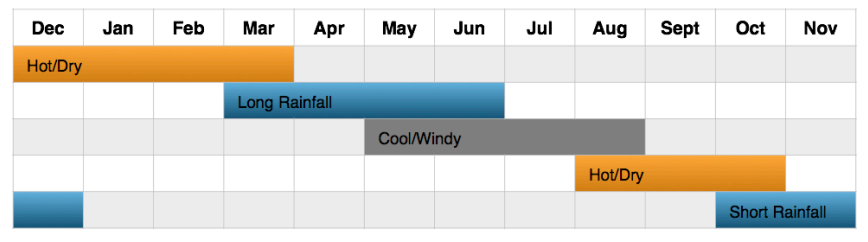


samples for each of the available WEPs mentioned by survey respondents and identified during participatory activities were collected with help from participants and field assistants (Appendix 1).

\section{Data analysis}

\section{Quantitative data analysis}

Data collected during the household surveys were entered into spreadsheets and converted for descriptive statistical analysis using Stata 11.2 (Stata 2011). The main variable of interest, WEP consumption frequency, was determined by extrapolating weekly consumption data collected in household surveys, which also specified the number of weeks or months per year each consumed WEP species was available, harvested, and eaten by household members. A single event was defined as the consumption of the specified WEP in a meal or as a snack, whatever the quantity involved. Thus, a bunch of leafy greens added to a stew was considered on the same scale as a handful of berries eaten on the way to collect water. We did consider the potential confounding effects of recall bias over the 12-month survey period, as well as the possible exclusion of consumption data from children or other family members not present during the interview (Delang 2006a, b). However, during home visits, we found that the survey questions were often answered collaboratively by several family members who made an effort to represent the consumption patterns of their relatives by singling out specific groups such as children, pregnant women, and elders when discussing WEP species preferences, harvest activities, and consumption rates (Appendix 2). There is also evidence that supports collecting recent data first and using relatively short timeframes (24-h recall, weekly consumption data) as compared to longer periods for data on children's diets collected from adults (Engebretsen et al. 2007), which we considered in our survey design. Qualitative data were also collected during activities with local schools to corroborate information obtained from the parents about harvest activity by young people as a means of triangulating the information obtained from adult reporters, which was found to minimize bias in other studies of youth diets (Oldewage-Theron et al. 2006).

Means of household characteristics and annual household WEP consumption were compared between study sites using $t$-tests for two independent samples. Percentages of households collecting WEPs from different harvest areas (e.g., homestead, neighbor's farms) were also compared between sites using $Z$-tests for two proportions. At the seasonal level, the relationship between the average monthly WEP harvest per household and the monthly percentage of food-insecure households was estimated using Spearman rank correlation.

Data on the different reasons or motivations given by the survey respondents for harvesting WEPs were analysed by calculating the incidence (i.e., 0 or 1 ) of a given motivation for different types of WEPs (fruit, vegetables) and harvest locations (e.g., homestead, own farms, hills). For each motivation type, a $t$-test for two independent samples was used to compare means of occurrence between a given harvest area type and all the other area types combined. This analysis was performed to examine whether there was a relationship between reasons for harvest and types of harvest areas.
Ordinary least squares multiple linear regression was used for different harvest area types to determine household, farm, and access factors that had a significant effect on consumption of WEPs. A first set of multiple linear regressions was performed to identify household characteristics influencing the annual WEP household consumption coming from the different harvest area types. A second set of multiple linear regressions was conducted to determine what household characteristics and access variables (e.g., permission, distance) could explain the quantity of WEPs consumed from individual harvest locations belonging to different harvest area types. WEP consumption was logtransformed to create a more normal distribution for the regression analysis.

\section{Qualitative data analysis}

The qualitative data collected in focus group discussions, preference-ranking sessions, and seasonal mapping activities were analyzed to help inform the quantitative data collection and analysis, complementing our understanding of the issues at hand. Focus group discussions were approached using the constant comparison technique (Glaser and Strauss 1967), which involves creating broad categories of incidents (in this case, discussion topics and responses) that are later used to develop theories that can be applied to the research question (Grove 1988). Preference ranking sessions were analyzed with help from participants during the discussion following each event to identify consensus or disagreement regarding the use and desirability of various WEP species (Marshall and Newton 2003, Medley and Kalibo 2005, Latif et al. 2006).

Data collected during participatory activities such as seasonal mapping rely on participants to explain the meaning behind diagrams or conversations by answering the researchers' questions about the specifics of their representation or helping compare their views with data collected using other methods (Kesby 2000). We sought input from session actors during followup discussion to help interpret the data collected, and then used the information to create graphs showing relative trends in food security, crop, and cash availability, as well as WEP consumption and abundance (Freudenberger et al. 1997, Catley et al. 2002, Günther and Vogl 2010).

\section{Spatial analysis}

The GPS points collected for each harvest location were mapped using ArcGIS (ESRI 2010, Scott and Janikas 2010) with base layers from the Africover project within the Global Land Cover Network Alliance (http://www.fao.org/geonetwork/srv/en/main. search?title=africover). Although spatial patterns in WEP harvests could be associated with spatial patterns in household, farm, and access explanatory variables, they might also suggest the presence of spatially structured factors not considered in the study such as environmental conditions that could affect WEP availability. A spatial analysis was thus conducted to determine the presence, or not, of spatial autocorrelation, i.e., clusters or hot-spots of higher WEP values (Kelly-Hope et al. 2009, Kent and Capello 2013). Spatial analysis techniques mentioned in previous studies (Foody 2004, Pineda Jaimes et al. 2010) were used and included, for each study area, a correlogram based on the global Moran's I statistic calculated at different distance lags using the Incremental Spatial Autocorrelation tool of ArcGIS and the estimation of the Getis-Ord Gi* statistic. Moran's I compares each point with its neighbors to see if the values are 
Table 1. Mean (SD) of various household characteristics and wild edible plant (WEP) harvest in Gantundu and Nyukani, Kenya. Sites were compared for each variable using $t$-tests. Percentages of household harvesting WEPs in the two sites were compared using a chisquare test.

\begin{tabular}{|c|c|c|}
\hline \multirow[b]{2}{*}{ Household characteristic } & \multicolumn{2}{|c|}{ Study site } \\
\hline & Gantundu & Nyukani \\
\hline Food insecure $\dagger$ & $0.6(0.498)$ & $0.9(0.305)^{* *}$ \\
\hline Head of household completed primary school $\dagger$ & $0.3(0.479)$ & $0.1(0.254)^{* *}$ \\
\hline Value of assets (Ksh) & $15,641(11,328)$ & $4083(3986)^{* * *}$ \\
\hline Head of household $<40$ years old $\dagger$ & $0.5(0.507)$ & $0.3(0.479)$ \\
\hline Head of household away from home $\dagger$ & $0.4(0.498)$ & $0(0.183)^{* *}$ \\
\hline Work is primarily off-farm $\dagger$ & $0.5(0.507)$ & $0.2(0.407)^{* *}$ \\
\hline Total number of children $(<15$ years old $)$ & $1.6(1.33)$ & $1.9(2.03)$ \\
\hline Female respondent $\dagger$ & $0.7(0.479)$ & $0.5(0.507)$ \\
\hline Single-female household $\dagger$ & $0.2(0.407)$ & $0.1(0.305)$ \\
\hline Single-male household $\dagger$ & $0(0.183)$ & $0.2(0.379)$ \\
\hline Total farm size (ha) & $4.3(2.52)$ & $3.6(2.38)$ \\
\hline \multicolumn{3}{|l|}{ Number of households harvesting WEPs from: } \\
\hline Homestead or qwn farm & $30[100 \%]$ & $30[100 \%]$ \\
\hline Off-farm natural areas & $18[60 \%]$ & $28[93 \%]^{* *}$ \\
\hline Neighbors' farms & $20[67 \%]$ & $23[73 \%]$ \\
\hline Mean annual household total WEP harvest & $230(166.6)$ & $465.5(277.3)^{* *}$ \\
\hline
\end{tabular}

$\uparrow$ Coded as dummy variables ( $1=$ condition fulfilled, $0=$ condition not fulfilled).

$* \mathrm{P}<0.05,{ }^{* *} \mathrm{P}<0.01,{ }^{* * *} \mathrm{P}<0.001$.

more similar (or dissimilar) than random numbers; the Global Getis-Ord $\mathrm{Gi}^{*}$ is a hot-spot analysis statistic that identifies clusters where the points have higher or lower values than those predicted by chance. At the level of the whole study area, geographic variation between the two study areas was essentially captured by the average annual WEP consumption obtained at each study site.

\section{RESULTS AND DISCUSSION}

\section{Descriptive statistics of the study areas}

The Gantundu case study location is located approximately 10 $\mathrm{km}$ from Nyukani and the nearest protected area (Fig. 1) and has been exposed to many more interventions from nongovernmental organizations (NGOs), government extension agents, and development projects such as the "work for food" program, in addition to being part of the on-site agricultural trials for the KARI-McGill project. When statistics from household surveys were compared, Gantundu had significantly higher household assets and less food insecurity, perhaps due to greater average education level for the household head and more of the major breadwinners working primarily off-farm and away from the village (Table 1). The trend toward lower income, food security, and opportunity in Nyukani is supported by other studies, which have found that rural poverty and under-nutrition rates are often higher near biodiversity hot-spots and conservation areas (McNeely and Scherr 2001, Naughton-Treves et al. 2005) such as the Kijege Reserve adjacent to the village of Nyukani.

As expected, due to significant differences in socioeconomic indicators and self-reported food security (Lewu and Mavengahama 2010), WEP collection practices between the two case study sites showed a strong trend toward greater frequency of WEP collection from homes, off-farm areas, and overall, and a larger percentage of households collecting in off-farm areas from the village of Nyukani (Table 1). On average, Nyukani households consumed more WEPs from all harvest areas than did Gantundu households, with the percentage of households gathering WEPs from any given harvest site following a similar trend. Despite some differences in consumption rates and harvest practice, many of the general preferences for certain wild fruits and vegetables, harvester roles, and reasons for consumption determined during community meetings and focus-group freelisting sessions were consistent across the study sites (see examples in Appendix 2).

Motivations for WEP consumption were revisited during the household survey, during which respondents could describe their reasons using one or all of the available options. Some clear trends by WEP type emerged, which were consistent between the two sites:

1. Vegetables were often consumed due to hunger, medicinal needs, and perceived vitamin benefits.

2. Fruits tended to be eaten for "fun" or their taste.

3. Food-insecure households often collected WEPs due to hunger.

4. Households with high levels of assets were likely to base their harvests on taste and less likely to collect vegetables.

We found that taste and fun are major drivers of WEP harvest, but also that significant portions of these resources are consumed specifically to supplement diets lacking in calories and micronutrients. Motivations such as vitamins and hunger suggest that the respondent is having difficulty obtaining adequate nutrition and is using alternative livelihood strategies to overcome food insecurity for themselves and their household members.

Results on motivations to harvest WEPs were separated by harvest area to assess whether these areas were visited for different 
Table 2. Relationship between survey respondent motivations for harvesting/consuming wild edible plants and types of harvest areas. A positive (negative) sign indicates that the harvest area considered has a greater (lesser) incidence of a motivation, on average, than the other areas combined. Differences in mean incidence of motivations between harvest areas were compared using two-tailed $t$-tests

\begin{tabular}{|c|c|c|c|c|c|c|c|}
\hline \multirow[b]{2}{*}{ Variable } & \multirow[b]{2}{*}{ Category } & \multicolumn{6}{|c|}{ Motivation } \\
\hline & & Fun & Taste & Hunger & Vitamin & Medicinal & Vegetable \\
\hline \multirow[t]{7}{*}{ Harvest area } & Home & +++ & $*$ & 0 & 0 & ++ & --- \\
\hline & Own farm & -- & -- & 0 & +++ & 0 & +++ \\
\hline & Other areas & 0 & 0 & 0 & -- & 0 & + \\
\hline & Hill & 0 & 0 & 0 & 0 & 0 & 0 \\
\hline & Forest & -- & ++ & --- & 0 & 0 & - \\
\hline & River & 0 & 0 & + & 0 & 0 & + \\
\hline & Neighbors' farms & 0 & $*$ & +++ & ++ & 0 & -- \\
\hline \multirow[t]{4}{*}{ Socioeconomic condition } & Food insecure & 0 & 0 & + & 0 & 0 & 0 \\
\hline & No assets & 0 & 0 & 0 & 0 & 0 & + \\
\hline & Moderate assets & + & $-*$ & 0 & 0 & $-*$ & 0 \\
\hline & High assets & 0 & ++ & 0 & 0 & 0 & - \\
\hline
\end{tabular}

Greater incidence compared to other areas: $* \mathrm{P}<0.1,+\mathrm{P}<0.05,++\mathrm{P}<0.01,+++\mathrm{P}<0.001$.

Lesser incidence compared to other areas: $-* \mathrm{P}<0.1,-\mathrm{P}<0.05,--\mathrm{P}<0.01,---\mathrm{P}<0.001$.

reasons (Table 2; Kristensen and Balslev 2003). Our results show that some areas such as farms, neighbors' farms, and riverbanks are visited for WEPs when hunger or vitamins are the main motivation. Other areas such as the home or riverbanks are often WEP collection sites for those seeking fruits that taste good or are eaten for fun. We believe it is important to make and explore this distinction because the benefits from WEPs for household food security vary by the type of foods collected and the reasons for their harvest due to seasonal availability and nutrition (Ogle and Grivetti 1985, Nordeide et al. 1996). Other researchers have also found that communities in rural Kenya view some WEP species as important sources of supplementary nutrition, whereas others are viewed more as minor components of the diet or "food for children" (Maundu 1996), which could be important as harvest regulations are developed in the future.

Seasonal variation in food security and wild edible plant harvest Fluctuating food availability and cash reserves are a common phenomenon in tropical environments where rainfall is unpredictable, an especially detrimental condition for poorer populations that lack the production capabilities (large farms, investment capital, and alternative incomes) to avoid food shortages (Chambers et al. 1981). We used participatory seasonal mapping activities to demonstrate the annual trends in household stocks of food from the farm and cash reserves, showing the abundance of resources during the hot season at the beginning of the year, approximately January-March, and significant declines through the beginning of the second rainy season (around September) for cash resources, and up until the major harvests in December for food available from the farm (Fig. 2). These seasonal trends in food insecurity have been documented in Kenya by other researchers (Kennedy and Cogill 1988), finding significantly higher calorie consumption between December and March, and the hungry season when food must often be purchased until crops can be harvested running from October to December (Ferguson 1986), similar to our findings.

There were also changes in abundance and consumption of WEPs across the calendar year, which we discussed by separating by WEP type (fruits and vegetables) and harvest location (farms vs. hills and riverbeds) to cover a range of harvest activities. We found dramatically different seasonal trends between different types of WEPs and their harvest, for example, the peaks in availability of fruit from the farm as compared to the hill and river harvest areas (Fig. 3A). Participants generally related WEP consumption to local abundance, explaining the consistent seasonal trend in vegetables found on the farm (Fig. 3B) and other groups, but in the case of fruits harvested on-farm, we found a distinct mismatch where consumption was relatively high despite low reported abundance based on one group's perception (Fig. 3C). These findings suggest that there is a great deal of seasonal variation in the availability and consumption of WEPs from different classes and harvest areas, some of which corresponds to periods of widespread food and cash deficits in the study communities. Other researchers have also found that the availability of most WEPs varies by season (Kuhnlein and Receveur 1996), which can provide researchers a means of differentiating between WEPs consumed by choice and those eaten by necessity (Byron and Arnold 1999).

Using the seasonal data from the household survey, we did not find a significant correlation between monthly household WEP consumption and percentage of food insecure households $(P=$ 0.5779; Fig. 4). Households that self-identified as food insecure during specific months did not show increased WEP consumption during specific food insecure months but did tend to consume WEPs with greater frequency overall (see results of multiple linear regression below). Although no clear relationship was observed on a monthly basis between the total household WEP consumption and food insecurity, there may also be a need to consider the relative importance of WEP consumption in the overall household diet during the most food-insecure months. From these descriptive statistics, it seems that consumption reaches higher levels during the start of the rainy seasons (April and October), when crops have not yet matured and stores from the previous harvest are often exhausted. Consumption is lowest during September, December, and January, which participants attributed mainly to greater species availability during the rainy season (see also Powell et al. 2011). 
Fig. 3. Availability and consumption of food from various sources throughout the year as perceived by study participants. (A) Availability of fruit from farms compared to fruit from hill and river harvest areas. Participants considered both the difference in species available in each type of harvest area and changes in harvest time based on microclimate variation due to elevation and water availability. (B) Availability and consumption of vegetables harvested from farms, showing participants' views that abundance often drives consumption of wild edible plants in the study areas. (C) Availability and consumption of fruits from farms, showing the exception to the majority of cases in which abundance drives consumption of wild edible plants, in this case, the spike in consumption during the second hot/dry season despite low abundance. Groups 1 and $2=$ Gantundu, Groups 3 and $4=$ Nyukani.
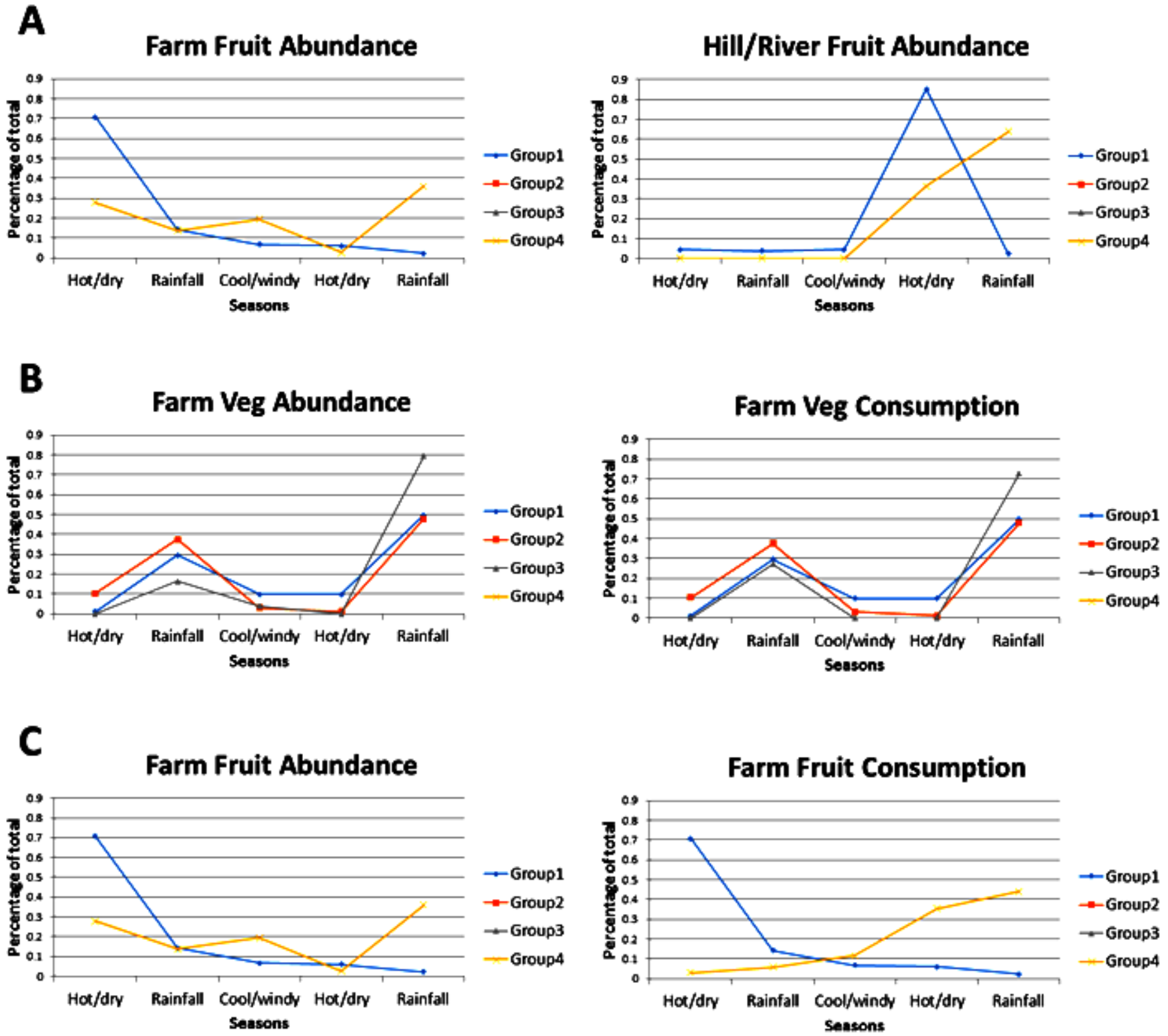

Indicators of household vulnerability that influence wild edible plant consumption

A number of household variables have been shown to affect the consumption frequency and species diversity of WEPs (Somnasang and Moreno-Black 2000, Byg and Balslev 2001, Reyes-García et al. 2005), many of which are related to sensitivity to environmental

changes and lack of resilience. In our study, these variables, including some additional conditions, were tested through the household survey by considering WEP consumption from personal homes and farms, neighbors' farms, and off-farm areas such as rivers, forests, and hills. One of the strongest relationships observed was the value of household assets ${ }^{[2]}$, which had a 
Table 3. Multiple linear regression analysis of the effect of household characteristics on annual household wild edible plant consumption for different types of harvest areas and overall.

\begin{tabular}{|c|c|c|c|c|c|c|c|c|}
\hline Independent variable & $\begin{array}{l}\text { Model 1: Home } \\
\text { and farm } \\
\text { collection }\end{array}$ & SE & $\begin{array}{l}\text { Model 2: } \\
\text { Neighbors' farms } \\
\text { collection }\end{array}$ & SE & $\begin{array}{c}\text { Model 3: Off- } \\
\text { farm natural areas } \\
\text { collection }\end{array}$ & $\mathrm{SE}$ & $\begin{array}{l}\text { Model 4: All } \\
\text { harvest areas } \\
\text { combined }\end{array}$ & SE \\
\hline Food insecure $\dagger$ & $0.953 * *$ & 0.29 & $1.195^{* *}$ & 0.49 & 0.376 & 0.54 & $0.832 * * *$ & 0.25 \\
\hline Total number of children $(<15$ yrs old $)$ & 0.036 & 0.05 & -0.009 & 0.12 & 0.023 & 0.11 & 0.039 & 0.05 \\
\hline Value of assets $(100,000 \mathrm{Ksh})$ & -8.480 & 0.86 & $-5.09 *$ & 2.12 & $-8.4^{* *}$ & 2.66 & $-1.65^{*}$ & 0.78 \\
\hline Work primarily off-farm $\dagger$ & -0.164 & 0.19 & 0.500 & 0.50 & 0.076 & 0.53 & -0.050 & 0.16 \\
\hline Head of household awayt & 0.326 & 0.36 & 0.127 & 0.68 & -0.102 & 0.67 & 0.111 & 0.26 \\
\hline $\begin{array}{l}\text { Head of household completed primary } \\
\text { school } \dagger\end{array}$ & -0.274 & 0.33 & 0.080 & 0.42 & 0.061 & 0.61 & -0.221 & 0.27 \\
\hline Female respondent $\dagger$ & 0.505 & 0.26 & 0.727 & 0.62 & 0.668 & 0.48 & $0.558^{*}$ & 0.23 \\
\hline Head of household $<40$ years old $\dagger$ & $-0.545^{* *}$ & 0.20 & -0.296 & 0.48 & 0.177 & 0.40 & $-0.422 *$ & 0.18 \\
\hline Single-female household $\uparrow$ & -0.348 & 0.35 & $-1.2560^{\wedge}$ & 0.70 & $-1.476^{\wedge}$ & 0.91 & $-0.489^{\wedge}$ & 0.28 \\
\hline Single-male household $\uparrow$ & 0.360 & 0.29 & 0.931 & 0.71 & 0.464 & 0.75 & $0.572^{*}$ & 0.27 \\
\hline Constant & $4.551^{* * *}$ & 0.43 & $1.523^{*}$ & 0.74 & $3.156 * * *$ & 0.83 & $4.936 * * *$ & 0.37 \\
\hline $\mathrm{R}^{2}$ & 0.465 & & 0.261 & & 0.313 & & 0.489 & \\
\hline Adjusted $\mathrm{R}^{2}$ & 0.335 & & 0.111 & & 0.173 & & 0.395 & \\
\hline Number of observations & 60 & & 60 & & 60 & & 60 & \\
\hline
\end{tabular}

$\dagger$ Coded as dummy variables $(1=$ condition fulfilled, $0=$ condition not fulfilled).

$\wedge \mathrm{P}<0.1, * \mathrm{P}<0.05, * * \mathrm{P}<0.01, * * * \mathrm{P}<0.001$

significantly negative effect on annual WEP consumption from neighbors' farms, off-farm areas, and overall (Table 3). Several other studies have suggested that wealthier households, especially those with access to cash income from formal sector employment, rely significantly less on WEPs than do poorer households (Cavendish 2000, Arnold and Pérez 2001, Pandit and Thapa 2003, Ticktin 2004, Mithofer et al. 2006, Musaba and Sheehama 2009, FAO 2011c), consistent with our findings here. The effect of assets on the motivations behind WEP collection was also analyzed (Table 3), showing similar trends in which households with high asset levels were significantly more likely $(P<0.01)$ to gather WEPs for their taste and avoid vegetables, whereas those families with no assets and food insecurity were more likely to collect vegetables $(P<0.05)$ and be motivated by hunger $(P<0.05)$, respectively.

Fig. 4. Mean (SD) monthly consumption of wild edible plants (WEPs) and percentage of food insecure households throughout the year. These data were calculated from household surveys.

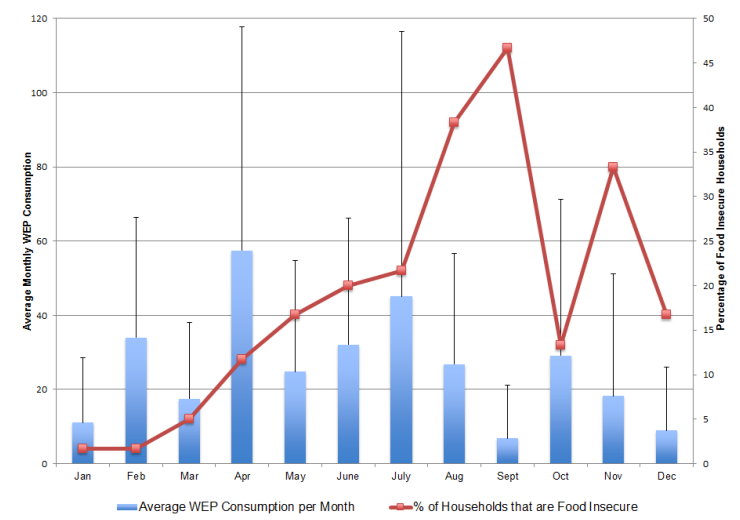

The results of the household survey also showed a strong relationship between self-reported food insecurity and increased WEP consumption from personal farms, neighbors' farms, and overall. As discussed above, WEP consumption often increases during hungry seasons and times of food crisis, but these results show a more general, year-round association of food-insecure families using WEPs as a coping mechanism. Other studies have found similar relationships, where wild foods are used by chronically food-insecure households on a daily basis to supplement nutrition, increase food volume, and stave off hunger (Harris and Mohammed 2003), especially for vulnerable groups such as AIDS-affected families, widows, and the landless (Campbell 1990, Grivetti and Ogle 2000, Kaschula 2008, Fentahun and Hager 2009, FAO 2011a).

\section{Local ecological knowledge, distance, and permission} requirements as indicators of capacity to access wild edible plants LEK is an important component of WEP harvest and consumption because it is near impossible to collect, prepare, and eat wild foods without knowledge of their habitat, toxicity, or seasonal abundance (Pilgrim et al. 2008). Many studies have examined the way that LEK affects WEP harvest, finding a relationship between LEK and the ethnobotanical skills necessary for successfully including wild foods in the diet, among other natural resource management and use activities (Reyes-Garciìa et al. 2008). Like any subset of knowledge, LEK has been found to vary by a number of testable demographic characteristics such as gender and age (see Styger et al. 1999, Shrestha and Dhillion 2006, Zobolo and Mkabela 2006, Pilgrim et al. 2007, Dovie et al. 2008), which were also considered in our household survey. Male respondents reported significantly less WEP consumption overall, and household heads $<40$ years old were also found to consume lower levels of WEPs from their personal farms and overall as compared to their older counterparts (Table 3). Nontraditional families, i.e., those headed by females or solitary males, were found to consume significantly different amounts of WEPs compared to other more traditional households, which 
Table 4. Multiple linear regression analysis of the effect of household characteristics, distance, permission requirements, and total farm size on annual wild edible plant consumption for individual harvest locations from different types of harvest area.

\begin{tabular}{|c|c|c|c|c|c|c|}
\hline Independent variable & $\begin{array}{l}\text { Model 1: Own } \\
\text { home and farm }\end{array}$ & $\mathrm{SE}$ & $\begin{array}{l}\text { Model 2: Off- } \\
\text { farm natural } \\
\text { areas }\end{array}$ & SE & $\begin{array}{c}\text { Model 3: } \\
\text { Neighbors' farms }\end{array}$ & SE \\
\hline Travel time to harvest (minutes) & -0.008 & 0.01 & $-0.009 *$ & 0.00 & -0.010 & 0.20 \\
\hline Permission required $\dagger$ & (omitted) $\sharp$ & (omitted) $\$$ & -0.062 & 0.45 & 2.900 & 2.13 \\
\hline Total farm size (ha) & $0.091 *$ & 0.04 & -0.068 & 0.09 & 0.126 & 0.11 \\
\hline Food insecure $\dagger$ & $0.862^{* *}$ & 0.27 & 0.765 & 0.51 & $1.197^{*}$ & 0.55 \\
\hline Total number of children $(<15$ years old $)$ & 0.033 & 0.56 & 0.082 & 0.10 & 0.035 & 0.14 \\
\hline Value of assets $(100,000 \mathrm{Ksh})$ & $-2.13 *$ & 0.9 & -3.86 & 2.67 & $-4.69^{\wedge}$ & 2.79 \\
\hline Work primarily off-farm $†$ & -0.258 & 0.20 & 0.131 & 0.47 & 0.941 & 0.58 \\
\hline Head of household away & 0.440 & 0.38 & 0.460 & 0.70 & 0.060 & 0.89 \\
\hline Head of household completed primary school $\dagger$ & -0.335 & 0.33 & 0.049 & 0.58 & 0.260 & 0.71 \\
\hline Female respondent $\dagger$ & $0.578^{*}$ & 0.26 & 0.189 & 0.45 & 1.092 & 0.58 \\
\hline Head of household $<40$ years old $\dagger$ & -0.283 & 0.19 & -0.637 & 0.41 & -0.063 & 0.53 \\
\hline Single-female household $\dagger$ & -0.238 & 0.24 & -0.935 & 0.79 & -0.642 & 0.83 \\
\hline Single-male household $\dagger$ & 0.307 & 0.38 & $1.318^{*}$ & 0.56 & 1.147 & 0.86 \\
\hline Constant & $4.221 * * *$ & 0.38 & $2.912 * * *$ & 0.815 & -2.208 & 2.68 \\
\hline $\mathrm{R}^{2}$ & 0.494 & & 0.283 & & 0.349 & \\
\hline Adjusted $\mathrm{R}^{2}$ & 0.350 & & 0.135 & & 0.113 & \\
\hline Number of observations§ & 55 & & 77 & & 50 & \\
\hline
\end{tabular}

$\lceil$ Coded as dummy variables $(1=$ condition fulfilled, $0=$ condition not fulfilled).

$\$$ Omitted from Model 1 due to collinearity: permission is never required for families to collect wild edible plants on their own farms.

$\S N u m b e r$ of observations varies across models because only those households that specified harvest areas where wild edible plants were collected were included in the regression.

$\wedge \mathrm{P}<0.1, * \mathrm{P}<0.05,{ }^{* *} \mathrm{P}<0.01, * * * \mathrm{P}<0.001$.

may be due in part to gender-based variation in LEK (Somnasang et al. 1998), which limits access where one sex does not have use of the traditional knowledge of the other.

Several studies have indicated that the availability of WEPs motivates their use, with the most popular species being those growing in the vicinity of the village (Pardo-De-Santayana et al. 2005, Arenas and Scarpa 2007). We considered the self-reported travel times to each harvest site (in minutes), collected during the household survey for each WEP harvested in nonfarm areas and neighboring private farms as a representation of the labor costs associated with each collection event (Campbell et al. 1997, Espinosa et al. 2011). Different harvest areas had a range of average transit times (Fig. 5), and longer travel times were found to correlate significantly with a decrease in consumption frequency in off-farm areas (Table 4). Travel time and distance have been shown to affect individual decisions to gather WEPs in other studies (Ladio and Lozada 2000), in relation to optimal foraging theory, which formalizes the cost-benefit analysis of expending energy (calories) to collect natural resources and how that affects harvester decision-making (Keegan 1986). Distance was not a significant factor in WEP collection from personal farms or neighbors' lands, which may be due to the common practice of harvesting WEPs during other activities, as discussed elsewhere (see Campbell and Luckert 2002, Delang 2006a) and during participatory mapping sessions.

The preference toward collecting WEPs during other livelihood activities may also explain our finding that WEPs collected on participants' own homes and farms are consumed $>5$ times more frequently on average than those harvested in any other area $(t$ test, $P<0.001)$. This is consistent with several other studies, which identify farms and their noncultivated edge areas as a major source of WEPs, especially weedy leafy vegetables and tree fruits (Price 1997, Cruz-Garcia and Price 2012). We also found a relationship between total farm size and annual WEP collection frequency $(P<0.05$; Table 4 , Model 1). The relationship between larger farms and higher WEP consumption may be due to generally higher plant species diversity on larger farms (Kindt et al. 2004), or possibly the amount of time spent on the farm due to greater labor demands related to increased acreage (Clay and Johnson 1992).

Fig. 5. Permission requirements for each harvest area, average number of species collected, and travel time to the area. Government-owned hilltops and private farms and forests located on private land require permission for wild edible plant harvesters, whereas riverbeds generally do not require permission. Number of species and travel time include only those households collecting from the specified harvest area.

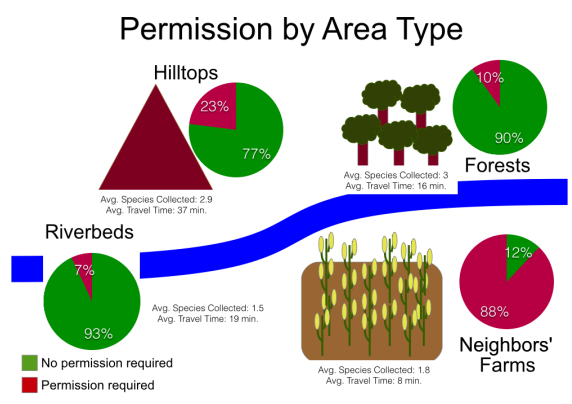


Variation in WEP access policies on private and public lands was a common theme that emerged during focus group discussions, interviews, and casual conversations, which has a large effect on the resilience of rural households and their ability to access WEPs as part of their adaptation to changing environmental and economic conditions (Shumsky et al. 2014). From data gathered during the household survey, trends emerged concerning permission requirements in different harvest areas (Fig. 5). WEPs harvested from sites that required permission were consumed approximately half as frequently as those that did not ( $t$-test, $P$ $<0.001$ ). However, when the sample was separated to exclude participants' own property, off-farm areas and neighbors' farms did not show significant correlation between WEP consumption frequency and permission requirements (Table 4). Although no statistically significant trends emerged for WEP consumption frequency and species diversity when permission requirements were considered, there may still be an effect because the household survey only included WEPs collected, and not those that the respondent might have liked to collect if harvest conditions were better (see Widayti et al. 2010). In the course of focus-group discussions and semi-structured interviews, participants raised concerns about theft, damage, and boundary changes due to unauthorized entry for WEP collection but did not specifically recount any instances when they had either stolen WEPs from neighbors or observed others doing so (for a detailed discussion see Shumsky et al. 2014).

\section{Spatial analysis}

From previous studies (Tabuti et al. 2004, Pardo-De-Santayana et al. 2005), we expected WEP consumption in Nyukani to be higher as a result of higher local biodiversity due to the proximity of a conservation area (Chapman and Chapman 2001) and higher altitude in general (Samant and Dhar 1997). Although this was observed in the original data (see Table 2), no significant differences between the two sites remained after the effects of household characteristics and access variables were taken into account in the multiple linear regression analysis. This suggests that the difference in WEP harvest between the sites can be primarily explained by differences in household characteristics and that the effect of the proximity to the conservation area, if present, was potentially confounded with these household characteristics.

Within each case study site, the Moran's I correlogram and the Getis-Ord Gi* statistic did not reveal significant spatial structures in the WEP consumption frequency (results not shown). These results further suggest that the majority of variation in WEP consumption can be predicted by household characteristics (Table 3 ) and the access conditions (Table 4) of specific harvest areas. Devineau et al. (2008) come to a similar conclusion following their GIS analysis of the availability and consumption of wild yams. They find that the use of this food resource does not correlate directly with the species distribution, but rather, they suggest that WEP consumption is related to factors outside of resource availability such as cultural traditions and unpredictable climate that increases vulnerability.

\section{Implications for rural social-ecological resilience in semi-arid Kenya}

The homogeneous geographic distribution of WEP consumption frequency within the two case-study sites suggests that household conditions and resource accessibility were the main factors affecting WEP consumption frequency. We relate these two categories to one another in a combined system (Fig. 6) describing how WEPs can be used to increase community resilience when household conditions and harvest practices are considered. Our results reveal several factors that affect the frequency and diversity

Fig. 6. Combined system illustrating how adaptive capacity and system sensitivity affect wild edible plant (WEP) contributions to community resilience.

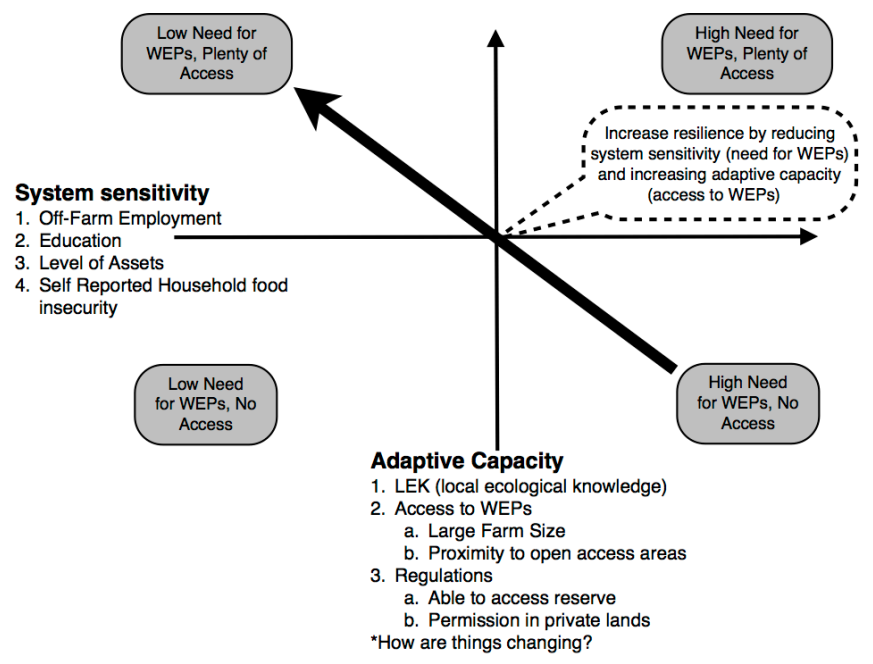

of WEPs consumed by the sample of rural Kenyans, both in terms of the need for these resources and the capacity to access them.

Household characteristics related to increased reliance on WEPs can be considered one measure of vulnerability or system sensitivity, which is how food insecurity, lack of off-farm income, and low assets have been identified previously (Ladio and Lozada 2003, Paumgarten 2005, Mithofer et al. 2006, Devineau et al. 2008). In addition to identifying WEP user-group demographics, other researchers have found WEP consumption trends and NTFP harvest activities related to access conditions and management regimes (Berkes et al. 2000, Pardo-De-Santayana et al. 2005, Widayati et al. 2010). Few reports consider both system sensitivity and coping capacity in the context of WEPs' contributions to social-ecological system resilience. Our theoretical model (Fig. 6) suggests that increased resilience can be achieved by reducing system sensitivity (promoting off-farm employment, reducing food insecurity, and augmenting household asset value) while also increasing access to adaptive measures.

In Kenya, the nutritional benefits of WEPs and traditional foods are a common topic of scientific study (Ogoye-Ndegwa 2003, Muthoni and Nyamongo 2010), but the importance of access to common areas where these products are harvested is often overlooked (Cousins 1999), and harvest restrictions in protected areas can shut out users who rely on WEPs (Falconer 1990). Lifting access restrictions in areas where WEPs are harvested primarily for food and micronutrient properties could benefit users that rely on them to combat malnutrition. This has been 
suggested in other studies, which demonstrate the nutritional benefits of WEP consumption for vulnerable groups and during times of food insecurity (Kengni et al. 2004, Mithöfer and Waibel 2004, Dovie et al. 2007), especially for communities where open access to NTFP resources is available (Dovie et al. 2007).

In terms of harvest policies and extension activities, system sensitivity factors could be used to identify groups that consume WEPs more frequently, helping NGOs and governments to target relevant projects more effectively. This is becoming more important as limited resources restrict food security initiatives in rural areas, despite increased need for these programs in the face of changing climate and increasingly vulnerable smallholder farms (Ifejika Speranza 2010). In some cases, inappropriately targeted interventions have increased income inequality (Harrigan 2003) or have overlooked supposed beneficiaries, i.e., subsistence farmers and poorer populations, when deciding on program participants (Belay and Abebaw 2004).

\section{CONCLUSION}

In this study, we sought to determine which household conditions are correlated with vulnerability and reliance on WEPs as a coping strategy during times of food insecurity while also investigating the role of access restrictions on adaptive capacity and the ability to obtain these important food resources. For two villages in rural Kenya, we found that reliance on WEPs was greater in households that reported food insecurity, lacked off-farm income, and had lower levels of assets. Access to WEPs was also a major factor in consumption frequency, with smaller farm sizes and increased distance to harvest areas correlated significantly to lower levels of WEP use. These variables are specific enough that they can be used to determine the demographic groups that rely heavily on WEPs and the access conditions that are likely to increase the ability of vulnerable groups to employ WEPs as a coping strategy to increase system resilience.

This research is unique in that we have combined vulnerability and adaptive capacity measures for each household to create a more complete accounting of the factors that influence WEP consumption frequency and the diversity of species consumed. These data can improve understanding of how common areas, marginal lands, and protected forests contribute to rural livelihoods on a daily basis and as emergency safety nets during hungry seasons. Specific, easily testable conditions such as offfarm income and self-reported food insecurity could make identifying user groups relatively simple for future projects and extension activities. The effects of farm size, distance to harvest areas, and ownership conditions on WEP access have been clearly identified in this study, which can inform future extraction regulations and land tenure reforms.

This study represents an important first step in taking a more holistic view of the important subsistence value of NTFPs such as WEPs, and the myriad factors that influence households' reliance on natural resources and their ability to obtain such products. As land tenure becomes increasingly formalized in Kenya, access to common property resources is decreasing (Migot-Adholla et al. 1991, Rutten 1997), and forest laws are making entry into protected areas more difficult for fragmented and impoverished rural communities that traditionally gained benefits from these areas (Laird et al. 2010). WEP resource use in the future is dependent on long-sighted policies that better consider the needs of user groups in scientific research, development policy, and extension activities (Feyssa et al. 2011). This becomes especially significant as climate change increases the pressure on institutions to foster social-ecological resilience (Folke et al. 2002, Ericksen 2008). If government and community regulations fail to consider the significance of WEPs to food security, the food production potential of their habitats is ignored, and household nutrition suffers (Dovie et al. 2007, Dansi et al. 2008), with potentially dire consequences in semi-arid Kenya, where food insecurity and failed crops are common (KFSSG 2011).

\section{Footnotes}

1. "Innovating for Resilient Farming Systems in Semi-Arid Kenya," funded by the Canadian International Food Security Research Fund (CIFSRF) (106510) through Foreign Affairs, Trade and Development Canada DFATD) and the International Development Research Centre (IDRC) (Principal Investigators: Gordon M. Hickey and Lutta W. Muhammad).

2. Determined by combining the average price (in Kenyan shillings) of household possessions like cell phones, bicycles and ploughs.

Responses to this article can be read online at: http://www.ecologyandsociety.org/issues/responses. $\mathrm{php} / 6924$

\section{Acknowledgments:}

This research was supported by the McGill University and KARI. We gratefully acknowledge the field assistants, translators, and especially the anonymous participants, for donating their valuable time and expertise to the study. We also acknowledge the support of Dr. Lutta Muhammad, the KARI Principal Investigator of the KARI-McGill Food Security Project. This work was carried out with the aid of a grant from the International Development Research Centre (IDRC), Ottawa, Canada, and with the financial support of the Government of Canada provided by Foreign Affairs, Trade and Development Canada (DFATD).

\section{LITERATURE CITED}

Addis, G., K. Urga, and D. Dikasso. 2005. Ethnobotanical study of edible wild plants in some selected districts of Ethiopia. Human Ecology 33(1):83-118. http://dx.doi.org/10.1007/s10745-005-1656-0

Adger, W. N., and K. Vincent. 2005. Uncertainty in adaptive capacity. Comptes Rendus Geoscience 337(4):399-410. http://dx. doi.org/10.1016/j.crte.2004.11.004

Arenas, P., and G. F. Scarpa. 2007. Edible wild plants of the Chorote Indians, Gran Chaco, Argentina. Botanical Journal of the Linnean Society 153(1):73-85. http://dx.doi.org/10.1111/ j.1095-8339.2007.00576.X

Arnold, J. E. M., and M. R. Pérez. 2001. Can non-timber forest products match tropical forest conservation and development objectives? Ecological Economics 39(3):437-447. http://dx.doi. org/10.1016/S0921-8009(01)00236-1 
Belay, K., and D. Abebaw. 2004. Challenges facing agricultural extension agents: a case study from south-western Ethiopia. African Development Review 16(1):139-168. http://dx.doi. org/10.1111/j.1467-8268.2004.00087.X

Below, T. B., K. D. Mutabazi, D. Kirschke, C. Franke, S. Sieber, R. Siebert, and K. Tscherning. 2012. Can farmers' adaptation to climate change be explained by socio-economic household-level variables? Global Environmental Change 22(1):223-235. http://dx. doi.org/10.1016/j.gloenvcha.2011.11.012

Berkes, F., J. Colding, and C. Folke. 2000. Rediscovery of traditional ecological knowledge as adaptive management. Ecological Applications 10(5):1251-1262. http://dx.doi. org/10.1890/1051-0761(2000)010[1251:ROTEKA]2.0.CO;2

Betser, E. 1999. Rapid reconnaissance market survey on tamarind in Kenya. ICRAF, Nairobi, Kenya. [online] URL: http://outputs. worldagroforestry.org/record/1543/files/RP01190.PDF.

Bharucha, Z., and J. Pretty. 2010. The roles and values of wild foods in agricultural systems. Philosophical Transactions of the Royal Society B 365(1554):2913-2926. http://dx.doi.org/10.1098/ rstb.2010.0123

Brooks, N., W. N. Adger, and P. M. Kelly. 2005. The determinants of vulnerability and adaptive capacity at the national level and the implications for adaptation. Global Environmental Change 15 (2):151-163. http://dx.doi.org/10.1016/j.gloenvcha.2004.12.006

Brown, K., and S. Lapuyade. 2001. A livelihood from the forest: gendered visions of social, economic and environmental change in southern Cameroon. Journal of International Development 13 (8):1131-1149. http://dx.doi.org/10.1002/jid.802

Brown, M. E., and C. C. Funk. 2008. Food security under climate change. Science 319(5863):580-581. http://dx.doi.org/10.1126/ science. 1154102

Burlingame, B. 2000. Wild nutrition. Journal of Food Composition and Analysis 13(2):99-100. http://dx.doi.org/10.1006/jfca.2000.0897

Byg, A., and H. Balslev. 2001. Traditional knowledge of Dypsis fibrosa (Arecaceae) in eastern Madagascar. Economic Botany 55 (2):263-275. http://dx.doi.org/10.1007/BF02864564

Byron, N., and M. Arnold. 1999. What futures for the people of the tropical forests? World Development 27(5):789-805. http://dx. doi.org/10.1016/S0305-750X(99)00025-X

Campbell, B. M., M. Luckert, and I. Scoones. 1997. Local-level valuation of savanna resources: a case study from Zimbabwe. Economic Botany 51(1):59-77. http://dx.doi.org/10.1007/BF02910405

Campbell, B., A. Mandondo, N. Nemarundwe, B. Sithole, W. De Jong, M. Luckert, and F. Matose. 2001. Challenges to proponents of common property recource systems: despairing voices from the social forests of Zimbabwe. World Development 29(4):589-600. http://dx.doi.org/10.1016/S0305-750X(00)00114-5

Campbell, B. M., and M. K. Luckert, editors. 2002. Uncovering the hidden harvest: valuation methods for woodland and forest resources. Earthscan, London, UK.

Campbell, D. J. 1990. Strategies for coping with severe food deficits in rural Africa: a review of the literature. Food and Foodways: Explorations in the History and Culture of Human
Nourishment 4(2):143-162. http://dx.doi.org/10.1080/07409710.1990.9961976

Catley, A., J. Osman, C. Mawien, B. A. Jones, and T. J. Leyland. 2002. Participatory analysis of seasonal incidences of diseases of cattle, disease vectors and rainfall in southern Sudan. Preventive Veterinary Medicine 53(4):275-284. http://dx.doi.org/10.1016/ S0167-5877(01)00289-6

Cavendish, W. 2000. Empirical regularities in the povertyenvironment relationship of rural households: evidence from Zimbabwe. World Development 28(11):1979-2003. http://dx.doi. org/10.1016/S0305-750X(00)00066-8

Chambers, R., R. Longhurst, and A. Pacey. 1981. Seasonal dimensions to rural poverty. Frances Pinter, London, UK.

Chapman, J. D., and H. M. Chapman. 2001. The forests of Taraba and Adamawa states, Nigeria: an ecological account and plant species checklist. Department of Plant and Microbial Sciences, University of Canterbury, Christchurch, New Zealand.

CIDA [Canadian International Development Agency]. 2004. Canada's 3rd report to the UNCCD on initiative undertake to combat desertification in Africa 2002-2004. UNCCD, Canadian International Development Agency, Bonn, Germany.

Clay, D. C., and N. E. Johnson. 1992. Size of farm or size of family: which comes first? Population Studies 46(3):491-505. http://dx.doi.org/10.1080/0032472031000146476

Cousins, B. 1999. Invisible capital: the contribution of communal rangelands to rural livelihoods in South Africa. Development Southern Africa 16(2):299-318. http://dx.doi.org/10.1080/03768$\underline{359908440079}$

Creswell, J. W. 2003. Research design: qualitative, quantitative, and mixed approaches. Sage, Thousand Oaks, California, USA.

Cruz-Garcia, G. S., and L. L. Price. 2012. Weeds as important vegetables for farmers. Acta Societatis Botanicorum Poloniae 81 (4):397-403. http://dx.doi.org/10.5586/asbp.2012.047

Dansi, A., A. Adjatin, H. Adoukonou-Sagbadja, V. Faladé, H. Yedomonhan, D. Odou, and B. Dossou. 2008. Traditional leafy vegetables and their use in the Benin Republic. Genetic Resources and Crop Evolution 55(8):1239-1256. http://dx.doi.org/10.1007/ s10722-008-9324-Z

Davies, S. 1993. Are coping strategies a cop out? IDS Bulletin 24 (4):60-72. http://dx.doi.org/10.1111/j.1759-5436.1993.mp24004007. $\underline{x}$

Delang, C. O. $2006 a$. Not just minor forest products: the economic rationale for the consumption of wild food plants by subsistence farmers. Ecological Economics 59(1):64-73. http://dx.doi. org/10.1016/j.ecolecon.2005.10.006

Delang, C. O. 2006b. Indigenous systems of forest classification: understanding land use patterns and the role of NTFPs in shifting cultivators' subsistence economies. Environmental Management 37(4):470-486. http://dx.doi.org/10.1007/s00267-005-0097-2

Devineau, J.-L., A. Aurouet, M. Douanio, and A. Hladik. 2008. Changes in the availability and uses of wild yams according to climatic dryness and land-cover in western Burkina Faso (West Africa): a joint ecological and ethno-botanical approach using 
GIS and remote-sensing. Biodiversity and Conservation 17 (8):1937-1963. http://dx.doi.org/10.1007/s10531-008-9338-z

Dovie, D. B. K., C. M. Shackleton, and E. T. F. Witkowski. 2007. Conceptualizing the human use of wild edible herbs for conservation in South African communal areas. Journal of Environmental Management 84(2):146-156. http://dx.doi.org/10.1016/ j.jenvman.2006.05.017

Dovie, D. B. K., E. T. F. Witkowski, and C. M. Shackleton. 2008. Knowledge of plant resource use based on location, gender and generation. Applied Geography 28(4):311-322. http://dx.doi. org/10.1016/j.apgeog.2008.07.002

Easterling, W. E., P. K. Aggarwal, P. Batima, K. M. Brander, L. Erda, S. M. Howden, A. Kirilenko, J. Morton, J.-F. Soussana, J. Schmidhuber, and F. N. Tubiello. 2007. Food, fibre and forest products. Pages 273-314 in M. Perry and O. Canziani, editors. Climate change 2007: impacts, adaptation and vulnerability. Contribution of Working Group II to the Fourth Assessment Report of the Intergovernmental Panel on Climate Change, volume 4. Cambridge University Press, Cambridge, UK. [online] URL: http://www.ipcc.ch/pdf/assessment-report/ar4/wg2/ar4-wg2chapter5.pdf.

Ellis, F., and G. Bahiigwa. 2003. Livelihoods and rural poverty reduction in Uganda. World Development 31(6):997-1013. http:// dx.doi.org/10.1016/S0305-750X(03)00043-3

Ellis, F., and H. A. Freeman. 2004. Rural livelihoods and poverty reduction strategies in four African countries. Journal of Development Studies 40(4):1-30. http://dx.doi.org/10.1080/0022$\underline{0380410001673175}$

Ellis, F., and N. Mdoe. 2003. Livelihoods and rural poverty reduction in Tanzania. World Development 31(8):1367-1384. http://dx.doi.org/10.1016/S0305-750X(03)00100-1

Engebretsen, I. M. S., H. Wamani, C. Karamagi, N. Semiyaga, J. Tumwine, and T. Tylleskär. 2007. Low adherence to exclusive breastfeeding in eastern Uganda: a community-based crosssectional study comparing dietary recall since birth with 24-hour recall. BMC Pediatrics 7: 10. http://dx.doi.org/10.1186/1471-2431-7-10

Ericksen, P. J. 2008. Conceptualizing food systems for global environmental change research. Global Environmental Change 18 (1):234-245. http://dx.doi.org/10.1016/j.gloenvcha.2007.09.002

Eriksen, S. H., K. Brown, and P. M. Kelly. 2005. The dynamics of vulnerability: locating coping strategies in Kenya and Tanzania. Geographical Journal 171(4):287-305. http://dx.doi. org/10.1111/j.1475-4959.2005.00174.X

Eriksen, S. H., and K. O'brien. 2007. Vulnerability, poverty and the need for sustainable adaptation measures. Climate Policy 7 (4):337-352. http://dx.doi.org/10.1080/14693062.2007.9685660

Espinosa, C., G. Shepherd, and J. W. den Besten. 2011. Understanding forest dependency for REDD+: adapting the Forests-Poverty Toolkit to new purposes. Briefing paper. Internation Union for Conservation of Nature, Washington, D. C., USA. [online] URL: http://cmsdata.iucn.org/downloads/ briefing paper redd and forests poverty toolkit.pdf.

ESRI [Environmental Systems Research Institute]. 2010. ArcGIS. Release 10.0. Environmental Systems Research Institute, Redlands, California, USA.
Falconer, J. 1990. "Hungry season" food from the forests. Unasylva 41(160):14-19. [online] URL: http://www.fao.org/ docrep/t7750e/t7750e03.htm\#hungry season food from the forests.

FAO [Food and Agriculture Organisation]. 2011a. Forests for improved nutrition and food security. FAO, Rome, Italy. [online] URL: http://www.fao.org/docrep/014/i2011e/i2011e00.pdf.

FAO [Food and Agriculture Organisation]. 2011b. The state of food insecurity in the world: How does international price volatility affect domestic economies and food security? FAO, Rome, Italy. [online] URL: http://www.fao.org/docrep/014/i2330e/i2330e00. htm.

FAO [Food and Agriculture Organisation]. 2011c. State of the world's forests. FAO, Rome, Italy. [online] URL: http://www.fao. org/docrep/013/i2000e/i2000e00.htm.

FAO [Food and Agriculture Organisation]. 2012. The state of food insecurity in the world: economic growth is necessary but not sufficient to accelerate reduction of hunger and malnutrition. FAO, Rome, Italy. [online] URL: http://www.fao.org/publications/ sofi/2012/en/.

Fentahun, M. T., and H. Hager. 2009. Exploiting locally available resources for food and nutritional security enhancement: wild fruits diversity, potential and state of exploitation in the Amhara region of Ethiopia. Food Security 1(2):207-219. http://dx.doi. org/10.1007/s12571-009-0017-Z

Ferguson, A. 1986. Women's health in a marginal area of Kenya. Social Science and Medicine 23(1):17-29. http://dx.doi. org/10.1016/0277-9536(86)90320-5

Feyssa, D. H., J. T. Njoka, Z. Asfaw, and M. M. Nyangito. 2011. Seasonal availability and consumption of wild edible plants in semiarid Ethiopia: implications to food security and climate change adaptation. Journal of Horticulture and Forestry 3 (5):138-149. [online] URL: http://www.academicjournals.org/ journal/JHF/article-abstract/36F5B971295.

Folke, C., S. Carpenter, T. Elmqvist, L. Gunderson, C. S. Holling, and B. Walker. 2002. Resilience and sustainable development: building adaptive capacity in a world of transformations. Ambio 31(5):437-440. http://dx.doi.org/10.1579/0044-7447-31.5.437

Foody, G. M. 2004. Spatial nonstationarity and scale-dependency in the relationship between species richness and environmental determinants for the sub-Saharan endemic avifauna. Global Ecology and Biogeography 13(4):315-320. http://dx.doi. org/10.1111/j.1466-822X.2004.00097.X

Freudenberger, M. S., J. A. Carney, and A. R. Lebbie. 1997. Resiliency and change in common property regimes in West Africa: the case of the Tongo in the Gambia, Guinea, and Sierra Leone. Society and Natural Resources 10(4):383-402. http://dx. doi.org/10.1080/08941929709381036

Glaser, B. G., and A. L. Strauss. 1967. The discovery of grounded theory: strategies for qualitative research. Aldine de Gruyter, Piscataway, New Jersey, USA.

Godfray, H. C. J., J. R. Beddington, I. R. Crute, L. Haddad, D. Lawrence, J. F. Muir, J. Pretty, S. Robinson, S. M. Thomas, and 
C. Toulmin. 2010. Food security: the challenge of feeding 9 billion people. Science 327(5967):812-818. http://dx.doi.org/10.1126/ science. 1185383

Gordon, L. J., and E. I. Enfors. 2008. Land degradation, ecosystem services, and resilience of smallholder farmers in Makanya catchment, Tanzania. Pages 33-50 in D. Bossio and K. Geheb, editors. Conserving land, protecting water. CABI, Wallingford, UK. http://dx.doi.org/10.1079/9781845933876.0033

Grivetti, L. E., and B. M. Ogle. 2000. Value of traditional foods in meeting macro- and micronutrient needs: the wild plant connection. Nutrition Research Reviews 13(1):31-46. http://dx. doi.org/10.1079/095442200108728990

Grove, R. W. 1988. An analysis of the constant comparative method. Internation Journal of Qualitative Studies in Education 1 (3):273-279. http://dx.doi.org/10.1080/0951839900030105a

Günther, M., and C. R. Vogl. 2010. Visual participatory methods. BOKU University of Natural Resources and Applied Life Sciences, Vienna, Austria.

Harrigan, J. 2003. U-turns and full circles: two decades of agricultural reform in Malawi 1981-2000. World Development 31 (5):847-863. http://dx.doi.org/10.1016/S0305-750X(03)00019-6

Harris, F. M. A., and S. Mohammed. 2003. Relying on nature: wild foods in northern Nigeria. Ambio 32(1):24-29. http://dx.doi. org/10.1579/0044-7447-32.1.24

Heywood, V. 1999. Use and potential of wild plants in farm households. FAO Farm Systems Management Series. Food and Agriculture Organisation, Rome, Italy. [online] URL: http://www. fao.org/docrep/003/w8801e/w8801e00.htm.

Humphry, C. M., M. S. Clegg, C. L. Keen, and L. E. Grivetti. 1993. Food diversity and drought survival. The Hausa example. International Journal of Food Sciences and Nutrition 44(1):1-16. http://dx.doi.org/10.3109/09637489309017417

Ifejika Speranza, C. 2010. Resilient adaptation to climate change in African agriculture. German Development Institute, Bonn, Germany.

IUCN and UNEP [International Union for Conservation of Nature and United Nations Environment Programme]. 2010. The world database on protected areas (WDPA). UNEP-WCMC, Cambridge, UK.

Jama, B. A., A. M. Mohamed, J. Mulatya, and A. N. Njui. 2008. Comparing the "big five": a framework for the sustainable management of indigenous fruit trees in the drylands of East and Central Africa. Ecological Indicators 8(2):170-179. http://dx.doi. org/10.1016/j.ecolind.2006.11.009

Jman Redzic, S. 2006. Wild edible plants and their traditional use in the human nutrition in Bosnia-Herzegovina. Ecology of Food and Nutrition 45(3):189-232. http://dx.doi.org/10.1080/0367024$\underline{0600648963}$

Kaschula, S. A. 2008. Wild foods and household food security responses to AIDS: evidence from South Africa. Population and Environment 29(3-5):162-185. http://dx.doi.org/10.1007/ $\underline{\text { s11111-008-0068-7 }}$
Keegan, W. F. 1986. The optimal foraging analysis of horticultural production. American Anthropologist 88(1):92-107. http://dx.doi. org/10.1525/aa.1986.88.1.02a00060

Kelly, P. M., and W. N. Adger. 2000. Theory and practice in assessing vulnerability to climate change and facilitating adaptation. Climatic Change 47(4):325-352. http://dx.doi. org/10.1023/A:1005627828199

Kelly-Hope, L. A., J. Hemingway, and F. E. McKenzie. 2009. Environmental factors associated with the malaria vectors Anopheles gambiae and Anopheles funestus in Kenya. Malaria Journal 8: 268. http://dx.doi.org/10.1186/1475-2875-8-268

Kengni, E., C. M. F. Mbofung, M. F. Tchouanguep, and Z. Tchoundjeu. 2004. The nutritional role of indigenous foods in mitigating the HIV/AIDS crisis in West and Central Africa. International Forestry Review 6(2):149-160. http://dx.doi. org/10.1505/ifor.6.2.149.38392

Kennedy, E., and B. Cogill. 1988. The commercialization of agriculture and household-level food security: the case of southwestern Kenya. World Development 16(9):1075-1081. http:// dx.doi.org/10.1016/0305-750X(88)90110-6

Kent, J. D., and H. T. Capello Jr. 2013. Spatial patterns and demographic indicators of effective social media content during the Horsethief Canyon fire of 2012. Cartography and Geographic Information Science 40(2):78-89. http://dx.doi.org/10.1080/1523$\underline{0406.2013 .776727}$

Kepe, T. 2008. Beyond the numbers: understanding the value of vegetation to rural livelihoods in Africa. Geoforum 39(2):958-968. http://dx.doi.org/10.1016/j.geoforum.2007.10.004

Kesby, M. 2000. Participatory diagramming: deploying qualitative methods through an action research epistemology. Area 32(4):423-435. http://dx.doi.org/10.1111/j.1475-4762.2000. $\underline{\mathrm{tb} 00158 . \mathrm{x}}$

KFSSG [Kenya Food Security Steering Group]. 2011. The 2011 long rains season assessment report. Kenya Food Security Steering Group, Nairobi, Kenya. [online] URL: http://www.wfp.org/ content/kenya-2011-long-rains-season-assessment-august-2011.

Kindt, R., A. J. Simons, and P. Van Damme. 2004. Do farm characteristics explain differences in tree species diversity among western Kenyan farms? Agroforestry Systems 63(1):63-74. http:// dx.doi.org/10.1023/B:AGFO.0000049434.54654.97

Kristensen, M., and H. Balslev. 2003. Perceptions, use and availability of woody plants among the Gourounsi in Burkina Faso. Biodiversity and Conservation 12(8):1715-1739. http://dx. doi.org/10.1023/A:1023614816878

Kuhnlein, H. V., and O. Receveur. 1996. Dietary change and traditional food systems of indigenous peoples. Annual Review of Nutrition 16:417-442. http://dx.doi.org/10.1146/annurev.nutr.16.1.417

Kuhnlein, H. V., S. Smitasiri, S. Yesudas, L. Bhattacharjee, L. Dan, and S. Ahmed. 2004. Documenting traditional food systems of indigenous peoples: international case studies. Guidelines for procedures. Centre for Indigenous Peoples' Nutrition and Environment, McGill University, Sainte-Anne-de-Bellevue, Canada. [online] URL: http://www.mcgill.ca/files/cine/manual. pdf. 
Kusters, K., R. Achdiawan, B. Belcher, and M. Ruiz Pérez. 2006. Balancing development and conservation? An assessment of livelihood and environmental outcomes of nontimber forest product trade in Asia, Africa, and Latin America. Ecology and Society 11(2): 20. [online] URL: http://www.ecologyandsociety. org/vol11/iss2/art20/.

Ladio, A. H., and M. Lozada. 2000. Edible wild plant use in a Mapuche community of northwestern Patagonia. Human Ecology 28(1):53-71. http://dx.doi.org/10.1023/A:1007027705077

Ladio, A. H., and M. Lozada. 2003. Comparison of wild edible plant diversity and foraging strategies in two aboriginal communities of northwestern Patagonia. Biodiversity and Conservation 12(5):937-951. http://dx.doi.org/10.1023/A:1022873725432

Laird, S. A., R. J. McLain, and R. P. Wynberg, editors. 2010. Wild product governance: finding policies that work for non-timber forest products. Earthscan, London, UK.

Latif, A., Z. K. Shinwari, J. Hussain, and S. Murtaza. 2006. NTFPS: an alternative to forest logging in Minadam and Sultanar Valley Swat. Lyonia 11(2):15-21. [online] URL: http://www. lyonia.org/viewArticle.php?articleID=485.

Lewu, F., and S. Mavengahama. 2010. Wild vegetables in northern KwaZulu Natal, South Africa: current status of production and research needs. Science Research Essays 5(20):3044-3048. [online] URL: http://www.academicjournals.org/journal/SRE/articleabstract/80EB9A718814.

Marshall, E., and A. C. Newton. 2003. Non-timber forest products in the community of El Terrero, Sierra de Manantlán Biosphere Reserve, Mexico: Is their use sustainable? Economic Botany 57(2):262-278. http://dx.doi.org/10.1663/0013-0001(2003) 057[0262:NFPITC]2.0.CO;2

Maundu, P. M. 1996. Utilization and conservation status of wild food plants in Kenya. Pages 678-683 in L. J. G. van der Maesen, X. M. van der Burgt, and J. M. van Medenbach de Rooy, editors. The biodiversity of African plants. Proceedings XIVth AETFAT Congress 22-27 August 1994, Wageningen, The Netherlands. Kluwer, Dordrecht, The Netherlands. http://dx.doi. org/10.1007/978-94-009-0285-5 83

Mavengahama, S., M. McLachlan, and W. de Clercq. 2013. The role of wild vegetable species in household food security in maize based subsistence cropping systems. Food Security 5(2):227-233. http://dx.doi.org/10.1007/s12571-013-0243-2

McNeely, J. A., and S. J. Scherr. 2001. Common ground, common future: how ecoagriculture can help feed the world and save wild biodiversity. IUCN-The World Conservation Union, Geneva, Switzerland.

Medley, K. E., and H. W. Kalibo. 2005. An ecological framework for participatory ethnobotanical research at Mt. Kasigau, Kenya. Field Methods 17(3):302-314. http://dx.doi.org/10.1177/1525822$\underline{\mathrm{X} 05277462}$

Migot-Adholla, S., P. Hazell, B. Blarel, and F. Place. 1991. Indigenous land rights systems in sub-Saharan Africa: a constraint on productivity? World Bank Economic Review 5 (1):155-175. http://dx.doi.org/10.1093/wber/5.1.155

Mithöfer, D., and H. Waibel. 2004. Seasonal vulnerability to poverty and indigenous fruit use in Zimbabwe. Page 148 in K. J.
Peters, D. Kirschke, W. Manig, A. Bürkert, R. Schultze-Kraft, L. Bharati, C. Bonte-Friedheim, A. Deininger, N. Bhandari, and H. Weitkamp, editors. Rural poverty reduction through research for development and transformation. Conference proceedings October 5-7 2004, Humboldt-Universität, Berlin, Germany. Deutscher Tropentag, Köthen, Germany.

Mithofer, D., H. Waibel, and F. K. Akinnifesi. 2006. The role of food from natural resources in reducing vulnerability to poverty: a case study from Zimbabwe. International Association of Agricultural Economists 2006 annual meeting, August 12-18, Queensland, Australia.

Moseley, W. G. 2012. Famine myths: five misunderstandings related to the 2011 hunger crisis in the Horn of Africa. Dollars and Sense March 2012(299):17-21.

Müller, C., W. Cramer, W. L. Hare, and H. Lotze-Campen. 2011. Climate change risks for African agriculture. Proceedings of the National Academy of Sciences 108(11):4313-4315. http://dx.doi. org/10.1073/pnas.1015078108

Muller, J., and A. M. Almedom. 2008. What is "famine food"? Distinguishing between traditional vegetables and special foods for times of hunger/scarcity (Boumba, Niger). Human Ecology 36(4):599-607. http://dx.doi.org/10.1007/s10745-008-9179-0

Musaba, E. C., and E. Sheehama. 2009. The socio-economic factors influencing harvesting of Eembe (Berchemia discolor) wild fruits by communal households in the Ohangwena region, Namibia. Namibia Development Journal 2009(1):1-12.

Muthoni, J., and D. O. Nyamongo. 2010. Traditional food crops and their role in food and nutritional security in Kenya. Journal of Agricultural and Food Information 11(1):36-50. http://dx.doi. org/10.1080/10496500903466745

Naughton-Treves, L., M. B. Holland, and K. Brandon. 2005. The role of protected areas in conserving biodiversity and sustaining local livelihoods. Annual Review of Environment and Resources 30:219-252. http://dx.doi.org/10.1146/annurev.energy.30.050504.164507

Nelson, R., P. Kokic, S. Crimp, H. Meinke, and S. M. Howden. 2010. The vulnerability of Australian rural communities to climate variability and change: part I-conceptualising and measuring vulnerability. Environmental Science and Policy 13 (1):8-17. http://dx.doi.org/10.1016/j.envsci.2009.09.006

Nordeide, M. B., A. Hatløy, M. Følling, E. Lied, and A. Oshaug. 1996. Nutrient composition and nutritional importance of green leaves and wild food resources in an agricultural district, Koutiala, in southern Mali. International Journal of Food Sciences and Nutrition 47(6):455-468.

Ogle, B. M., and L. E. Grivetti. 1985. Legacy of the chameleon: edible wild plants in the kingdom of Swaziland, southern Africa. A cultural, ecological, nutritional study. Part IV - nutritional analysis and conclusions. Ecology of Food and Nutrition 17 (1):41-64. http://dx.doi.org/10.1080/03670244.1985.9990881

Ogoye-Ndegwa, C. 2003. Traditional gathering of wild vegetables among the Luo of western Kenya-a nutritional anthropology project. Ecology of Food and Nutrition 42(1):69-89. http://dx.doi. org/10.1080/03670240303114

Oldewage-Theron, W. H., E. G. Dicks, and C. E. Napier. 2006. Poverty, household food insecurity and nutrition: coping 
strategies in an informal settlement in the Vaal Triangle, South Africa. Public Health 120(9):795-804. http://dx.doi.org/10.1016/ j.puhe.2006.02.009

Pandit, B. H., and G. B. Thapa. 2003. A tragedy of non-timber forest resources in the mountain commons of Nepal. Environmental Conservation 30(3):283-292. http://dx.doi.org/10.1017/ $\underline{\mathrm{S} 0376892903000286}$

Pardo-De-Santayana, M., J. Tardío, and R. Morales. 2005. The gathering and consumption of wild edible plants in the Campoo (Cantabria, Spain). International Journal of Food Sciences and Nutrition 56(7):529-542. http://dx.doi.org/10.1080/09637480500490731

Paumgarten, F. 2005. The role of non-timber forest products as safety-nets: a review of evidence with a focus on South Africa. GeoJournal 64(3):189-197. http://dx.doi.org/10.1007/s10708-005-5647$\underline{\mathrm{X}}$

Peach Brown, H. C., and J. P. Lassoie. 2010. The interaction between market forces and management systems: a case study of non-wood forest products in the humid forest zone of Cameroon. International Forestry Review 12(1):13-26. http://dx.doi. org/10.1505/ifor.12.1.13

Pilgrim, S., L. Cullen, D. Smith, and J. Pretty. 2007. Hidden harvest or hidden revenue? Local resource use in a remote region of southeast Sulawesi, Indonesia. Indian Journal of Traditional Knowledge 6(1):150-159.

Pilgrim, S. E., L. C. Cullen, D. J. Smith, and J. Pretty. 2008. Ecological knowledge is lost in wealthier communities and countries. Environmental Science and Technology 42(4):1004-1009. http://dx.doi.org/10.1021/es070837v

Pineda Jaimes, N. B., J. Bosque Sendra, M. Gómez Delgado, and R. Franco Plata. 2010. Exploring the driving forces behind deforestation in the state of Mexico (Mexico) using geographically weighted regression. Applied Geography 30 (4):576-591. http://dx.doi.org/10.1016/j.apgeog.2010.05.004

Powell, B., J. Hall, and T. Johns. 2011. Forest cover, use and dietary intake in the East Usambara Mountains, Tanzania. International Forestry Review 13(3):305-317. http://dx.doi.org/10.1505/146554811798293944

Price, L. L. 1997. Wild plant food in agricultural environments: a study of occurrence, management, and gathering rights in northeast Thailand. Human Organization 56(2):209-221.

Reyes-García, V., T. McDade, V. Vadez, T. Huanca, W. R. Leonard, S. Tanner, and R. Godoy. 2008. Non-market returns to traditional human capital: nutritional status and traditional knowledge in a native Amazonian society. Journal of Development Studies 44(2):217-232. http://dx.doi.org/10.1080/00220380701789901

Reyes-García, V., V. Vadez, T. Huanca, W. Leonard, and D. Wilkie. 2005. Knowledge and consumption of wild plants: a comparative study in two Tsimane' villages in the Bolivian Amazon. Ethnobotany Research and Applications 3:201-207. [online] URL: http://lib-ojs3.lib.sfu.ca:8114/index.php/era/article/ view/71/58.

Rutten, M. 1997. Land reform in Africa: lessons from Kenya. Pages 71-83 in T. van Naerssen, A. Zoomers, and M. Rutten, editors. The diversity of development: essays in honour of Jan Kleinpenning. Van Gorcum, Assen, The Netherlands.
Samant, S. S., and U. Dhar. 1997. Diversity, endemism and economic potential of wild edible plants of Indian Himalaya. International Journal of Sustainable Development and World Ecology 4(3):179-191. http://dx.doi.org/10.1080/13504509709469953

Sandemose, P. 2009. Local people and protected areas: the ban of NTFP collection for commercial use and effects on cash incomes and livelihoods of the Soligas in BR Hills, India. Thesis. Norwegian University of Life Sciences, Ås, Norway.

Scott, L. M., and M. V. Janikas. 2010. Spatial statistics in ArcGIS. Pages 27-41 in M. M. Fischer and A. Getis, editors. Handbook of applied spatial analysis: software tools, methods and applications. Springer, Berlin, Germany. http://dx.doi.org/10.1007/978-3-642-03647-7_2

Shackleton, C., and S. Shackleton. 2004. The importance of nontimber forest products in rural livelihood security and as safety nets: a review of evidence from South Africa. South African Journal of Science 100(11/12):658-654.

Shrestha, P. M., and S. S. Dhillion. 2006. Diversity and traditional knowledge concerning wild food species in a locally managed forest in Nepal. Agroforestry Systems 66(1):55-63. http://dx.doi. org/10.1007/s10457-005-6642-4

Shumsky, S., G. M. Hickey, T. Johns, B. Pelletier, and J. Galaty. 2014. Institutional factors affecting wild edible plant (WEP) harvest and consumption in semi-arid Kenya. Land Use Policy 38:48-69. http://dx.doi.org/10.1016/j.landusepol.2013.10.014

Sick, D. 2008. Social contexts and consequences of institutional change in common-pool resource management. Society and Natural Resources 21(2):94-105. http://dx.doi.org/10.1080/0894$\underline{1920701681524}$

Smucker, T. A., and L. U. Change. 2002. Land tenure reform and changes in land-use and land management in semi-arid Tharaka, Kenya. LUCID Project. International Livestock Research Institute, Nairobi, Kenya. [online] URL: http://hdl.handle. net/10568/1889.

Somnasang, P., G. Moreno, and K. Chusil. 1998. Indigenous knowledge of wild food hunting and gathering in north-east Thailand. Food and Nutrition Bulletin 19(4):359-365. [online] URL: http://nsinf.publisher.ingentaconnect.com/content/nsinf/ fnb/1998/00000019/00000004/art00012.

Somnasang, P., and G. Moreno-Black. 2000. Knowing, gathering and eating: knowledge and attitudes about wild food in an Isan village in northeastern Thailand. Journal of Ethnobiology 20 (2):197-216. [online] URL: http://ethnobiology.org/sites/default/ files/pdfs/JoE/20-2/SomnasangMoreno-Black.pdf.

Stata. 2011. Stata statistical software. Release 11.2. StataCorp, College Station, Texas, USA.

Stewart, K. M. 2003. The African cherry (Prunus africana): Can lessons be learned from an over-exploited medicinal tree? Journal of Ethnopharmacology 89(1):3-13. http://dx.doi.org/10.1016/j. jep.2003.08.002

Strauch, A. M., J. M. Muller, and A. M. Almedom. 2008. Exploring the dynamics of social-ecological resilience in East and West Africa: preliminary evidence from Tanzania and Niger. African Health Sciences 8(3):528-525. 
Styger, E., J. E. M. Rakotoarimanana, R. Rabevohitra, and E. C. M. Fernandes. 1999. Indigenous fruit trees of Madagascar: potential components of agroforestry systems to improve human nutrition and restore biological diversity. Agroforestry Systems 46 (3):289-310. http://dx.doi.org/10.1023/A:1006295530509

Sutherland, A. J., J. W. Irungu, J. Kang'ara, J. Muthamia, and J. Ouma. 1999. Household food security in semi-arid Africa-the contribution of participatory adaptive research and development to rural livelihoods in eastern Kenya. Food Policy 24(4):363-390. http://dx.doi.org/10.1016/S0306-9192(99)00050-0

Tabuti, J. R. S., S. S. Dhillion, and K. A. Lye. 2004. The status of wild food plants in Bulamogi County, Uganda. International Journal of Food Sciences and Nutrition 55(6):485-498. http://dx. doi.org/10.1080/09637480400015745

Termote, C., M. B. Meyi, J.-B. Ndjango, P. van Damme, B. D. A. Djailo, X. Burgt, J. Maesen, and J. Onana. 2010. Use and socioeconomic importance of wild edible plants in tropical rainforest around Kisangani, District Tshopo, DR Congo. Pages 417-427 in X. M. van der Burgt, L. J. G. van der Maesen, and J.-M. Onana, editors. Systematics and conservation of African plants. Proceedings of the 18th AETFAT Congress, Yaoundé, Cameroun, 26 February to 2 March 2007. Kew Publications, Richmond, UK.

Termote, C., P. Van Damme, and B. D. Djailo. 2011. Eating from the wild: Turumbu, Mbole and Bali traditional knowledge on non-cultivated edible plants, District Tshopo, DR Congo. Genetic Resources and Crop Evolution 58(4):585-618. http://dx.doi. org/10.1007/s10722-010-9602-4

Ticktin, T. 2004. The ecological implications of harvesting nontimber forest products. Journal of Applied Ecology 41(1):11-21. http://dx.doi.org/10.1111/j.1365-2664.2004.00859.x

United Nations. 2008. Designing household survey samples: practical guidelines. United Nations Educational, Statistical Division, New York, New York, USA.

Widayati, A., S. Jones, and B. Carlisle. 2010. Accessibility factors and conservation forest designation affecting rattan cane harvesting in Lambusango Forest, Buton, Indonesia. Human Ecology 38(6):731-746. http://dx.doi.org/10.1007/s10745-010-9358-7

Wisner, B. 1977. Constriction of a livelihood system: the peasants of Tharaka Division, Meru District, Kenya. Economic Geography 53(4):353-357. http://dx.doi.org/10.2307/142972

Yin, R. K. 2009. Case study research: design and methods. Fourth edition. Sage, Thousand Oaks, California, USA.

Yohe, G., and R. S. J. Tol. 2002. Indicators for social and economic coping capacity-moving toward a working definition of adaptive capacity. Global Environmental Change 12(1):25-40. http://dx.doi.org/10.1016/S0959-3780(01)00026-7

Zobolo, A. M., and Q. N. Mkabela. 2006. Traditional knowledge transfer of activities practised by Zulu women to manage medicinal and food plant gardens. African Journal of Range and Forage Science 23(1):77-80. http://dx.doi.org/10.2989/10220110609485889 


\begin{tabular}{|c|c|c|c|}
\hline Fruit Tree Name & Fruit Name & Family Name & Genus species \\
\hline Chiamaguna & $\begin{array}{c}\text { Mbuu } \\
\text { (tree variety) }\end{array}$ & Tiliaceae & Grewia villosa \\
\hline Gintujia & Ntugia & Euphorbiaceae & Tragia impedita \\
\hline Kirigurigu & - & Cactaceae & Opuntia ficus-indica \\
\hline Mubata mukundo & Batamukundo & Vitaceae & Cyphostemma adenocaule \\
\hline Mubiru & Mbiru & Rubiaceae & Vangueria madagascariensis \\
\hline Mubobua & Mbobua & Zygophyllaceae & Balanites aegyptiaca \\
\hline Mubuu & $\begin{array}{c}\text { Mbuu } \\
\text { (bush variety) }\end{array}$ & Tiliaceae & Grewia villosa \\
\hline Mubuyu & Buyu & Rhamnaceae & Ziziphus mucronata \\
\hline Mucimoro & Macimoro & Verbenaceae & Lantana camara \\
\hline Mucuura & Ncuura & Sapindaceae & Deinbollia kilimandscharica \\
\hline Mudura & Ndura & Tiliaceae & Grewia similis \\
\hline Mugumo & Ngumo & Moraceae & Ficus sp. \\
\hline Mujee & Njee & Euphorbiaceae & Bridelia taitensis \\
\hline Mujuria & Njuria & Malvaceae & Sterculia africana \\
\hline Mukawa, Mukagwa & Nkawa, Nkagwa & Apocynaceae & Carissa edulis \\
\hline Mukenia & Nkenia & Verbenaceae & Lantana trifolia \\
\hline Mukoro & Makoro & Ebenaceae & Diospyros mespiliformis \\
\hline Mukumangao & Nkumangao & Loganiaceae & Strychnos madagascariensis \\
\hline Mukunduthi & $\begin{array}{c}\text { Nkunduthi } \\
\text { (oval shaped variety) }\end{array}$ & Olacaceae & Ximenia americana \\
\hline Mukuru & Makuru & Annonaceae & Uvaria scheffleri \\
\hline Mukurungu & Nkurungu & Rubiaceae & Meyna tetraphylla \\
\hline Mukururu & Makururu & Euphorbiaceae & Flueggea virosa \\
\hline Mukuura & Makuura & Fabaceae & Piliostigma thonningii \\
\hline Mukuyu & Makuyu & Moraceae & Ficus sur \\
\hline Mungo (Moongo) & Maongo & Apocynaceae & Saba comorensis \\
\hline Mupuuru & Mpuuru & Verbenaceae & Vitex payos \\
\hline Muragwa & Ndagwa, Ndawa & Tiliaceae & Grewia bicolor \\
\hline Muramba & Uramba & Bombacaceae & Adansonia digitata \\
\hline Murenda & Ndenda & Tiliaceae & Grewia $s p$ \\
\hline Muroroma & $\begin{array}{c}\text { Ndoroma } \\
\text { (sphere shaped variety) }\end{array}$ & Olacaceae & Ximenia americana \\
\hline Muruguyu & Nduguyu, Ncomo & Arecaceae & Hyphaene compressa \\
\hline Muthana & Nthana & Capparidaceae & Maerua decumbens \\
\hline Mutherema & Ntherema & Anacardiaceae & Lannea rivae \\
\hline Muthigora & Nthigora & Combretaceae & Combretum aculeatum \\
\hline Muthigu & Mithigu & Bignoniaceae & Kigelia africana \\
\hline Muthithi & Uthithi & Fabaceae & Tamarindus indica \\
\hline
\end{tabular}




\begin{tabular}{|c|c|c|c|}
\hline Fruit Tree Name & Fruit Name & Family Name & Genus species \\
\hline Muthwana & Nthwana & Rhamnaceae & Berchemia discolor \\
\hline Mutoo & Matoo & Malvaceae & Azanza garckeana \\
\hline Mutuunka & Ntuunka & Rubiaceae & Tennantia sennii \\
\hline Muura & Maura & Anacardiaceae & Sclerocarya birrea \\
\hline Muyumu & Irumu & Fabaceae & Acacia senegal \\
\hline
\end{tabular}

\begin{tabular}{|c|c|c|}
\hline Local Vegetable Name & Family & Genus species \\
\hline Magendenakuru & Fabaceae & Senna didymobotrya \\
\hline Mathorokwe & Fabaceae & Vigna membranacea \\
\hline Mathuma-mbiti & Icacinaceae & Pyrenacantha kaurabassana \\
\hline Mathunju & Fabaceae & unknown \\
\hline $\begin{array}{c}\text { Maturankunu } \\
\text { (ruturankuru, kuturankunu) }\end{array}$ & Convolvulaceae & Ipomoea mombassana \\
\hline Mparia & Fabaceae & Clitoria ternatea \\
\hline Muchicha & Amaranthaceae & Amaranthus dubius \\
\hline Mucungurira & Cucurbitaceae & unknown \\
\hline Muthunka & Asteraceae & Launaea cornuta \\
\hline Ngatu & Cyperaceae & Cyperus blysmoides \\
\hline Ngonko & Polygonaceae & Oxygonum sinuatum \\
\hline Nkengejia & Commelinaceae & Commelina bengalensis \\
\hline Nkenia & Verbenaceae & Lantana trifolia \\
\hline Nkunda, Nkuuda & Fabaceae & Clitoria ternatea L. \\
\hline Nterere & Amaranthaceae & Amaranthus dubius \\
\hline Rugoya & Fabaceae & Indigofera lupatana \\
\hline Rwoga & Amaranthaceae & Amaranthus graecizans \\
\hline
\end{tabular}


Appendix II - Freelisting Preferences

\begin{tabular}{|c|c|c|c|c|c|c|c|c|c|c|c|c|c|}
\hline \multirow[t]{2}{*}{ Local Name } & \multirow{2}{*}{\begin{tabular}{|c|} 
Preference \\
0=Dislike; \\
1=Like; \\
2=Prefer to \\
crops \\
\end{tabular}} & \multicolumn{3}{|c|}{$\begin{array}{l}\text { Eaten } \\
\text { when: }\end{array}$} & \multicolumn{3}{|c|}{ Season } & \multicolumn{3}{|c|}{ Collected by } & \multicolumn{3}{|c|}{ Eaten by: } \\
\hline & & $\begin{array}{c}\text { Crops } \\
\text { fail }\end{array}$ & $\begin{array}{c}\text { No } \\
\text { cash }\end{array}$ & $\begin{array}{l}\text { For } \\
\text { fun }\end{array}$ & Rains & $\begin{array}{c}\text { Post- } \\
\text { rain }\end{array}$ & Dry & Kids & Women & Men & Kids & Elders & $\begin{array}{c}\text { Pregnant } \\
\text { women }\end{array}$ \\
\hline Muthunka & 2 & $x$ & $x$ & - & $x$ & $x$ & $x$ & - & $x$ & - & - & - & $x$ \\
\hline Mugendanankuru & 1 & $x$ & $x$ & - & $x$ & $x$ & - & - & $x$ & - & - & - & - \\
\hline Mparia & 1 & $x$ & $x$ & - & $x$ & - & - & - & $x$ & - & - & - & - \\
\hline Mathorokoe, & 1 & $x$ & $x$ & - & $x$ & - & - & - & $x$ & - & - & - & - \\
\hline Nkengejia & - & $x$ & $x$ & - & $x$ & $x$ & - & - & $x$ & - & - & - & - \\
\hline Terere & 2 & $x$ & $x$ & - & $x$ & - & - & - & $x$ & - & - & - & $x$ \\
\hline Rwoga & - & $x$ & $x$ & - & $x$ & - & - & - & $x$ & - & - & - & - \\
\hline Ngonko & 0 & $x$ & $x$ & - & $x$ & - & - & - & $x$ & - & - & - & $x$ \\
\hline Nthawana & 2 & $x$ & $x$ & - & \multirow{9}{*}{\multicolumn{3}{|c|}{$\begin{array}{c}\text { DATA NOT } \\
\text { COLLECTED }\end{array}$}} & $x$ & - & - & - & - & - \\
\hline Uthithi & 1 & $x$ & - & $x$ & & & & & - & $x$ & - & - & $x$ \\
\hline Mbuu & 1 & - & - & - & & & & & - & - & $x$ & $x$ & $x$ \\
\hline Nkururu & 1 & $x$ & - & $x$ & & & & $x$ & - & - & $x$ & $x$ & - \\
\hline Mboobua & 1 & - & $x$ & $x$ & & & & $x$ & - & - & $x$ & $x$ & - \\
\hline Ndoroma & 1 & - & $x$ & - & & & & $x$ & - & - & - & - & $x$ \\
\hline Mbiru & 1 & - & - & - & & & & & - & - & $x$ & $x$ & - \\
\hline Matoo & 1 & - & - & $x$ & & & & & - & - & $x$ & $x$ & - \\
\hline Uramba & 2 & $x$ & - & - & & & & & - & $x$ & - & - & - \\
\hline
\end{tabular}

\section{Eaten by Pregnant Women}

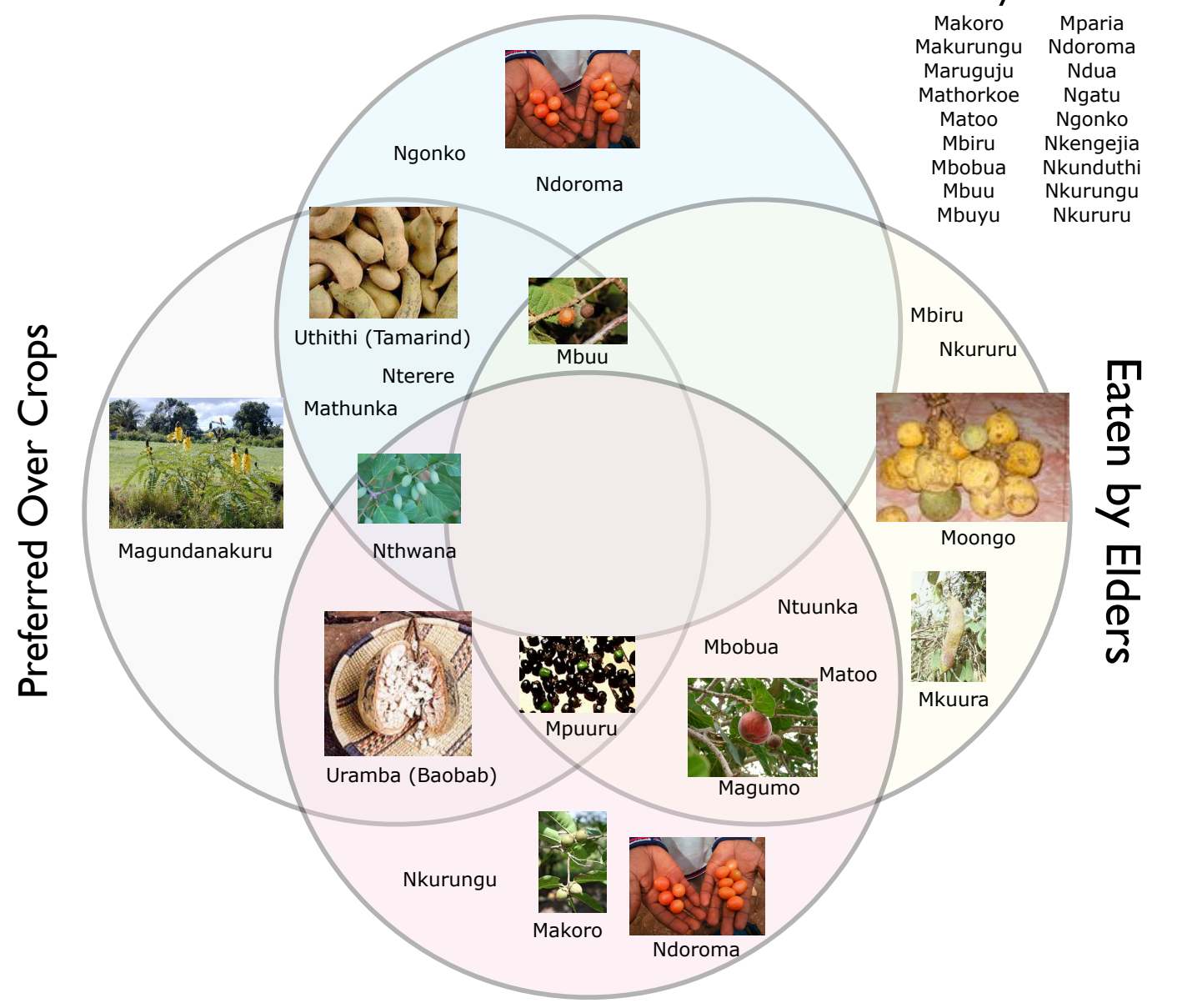

